Submitted, accepted and published by

International Journal of Greenhouse Gas Control 65 (2017) 76-85

\title{
Spray granulated Cu-Mn Oxygen Carrier for Chemical Looping with Oxygen Uncoupling (CLOU) Process
}

Iñaki Adánez-Rubio, María T. Izquierdo, Alberto Abad, Pilar Gayán*, Luis F. de Diego, Juan Adánez

Instituto de Carboquímica (ICB-CSIC), Dept. of Energy \& Environment, Miguel Luesma Castán, 4, Zaragoza, 50018, Spain

*Corresponding author. Tel.: +34 976 733977; fax: +34 976733318

Email address: pgayan@icb.csic.es

\begin{abstract}
One form of Chemical Looping Combustion (CLC) with $\mathrm{CO}_{2}$ capture as an alternative to the burning of solid fuels is the Chemical Looping with Oxygen Uncoupling (CLOU) process. The CLOU process requires metal oxides with $\mathrm{O}_{2}$ release capacity at temperatures that are suitable for solid fuel combustion, e.g. copper and manganese oxides. A Cu-Mn mixed oxide comprising $34 \mathrm{wt} \% \mathrm{CuO}$ and $66 \mathrm{wt} \% \mathrm{Mn}_{3} \mathrm{O}_{4}$ and prepared by fluidized bed granulation was analysed for use as an oxygen carrier for the CLOU process. TGA and batch fluidized bed reactors were used to investigate oxygen generation rates, agglomeration behaviour and oxygen carrier attrition. A medium volatile coal from South Africa and its char were used as fuel in a batch fluidized bed reactor in a temperature range of $800-930^{\circ} \mathrm{C}$. The $\mathrm{Cu}-\mathrm{Mn}$ oxygen carrier showed good release $\mathrm{O}_{2}$ rate and a high rate of oxygen transfer by direct gas-solid reaction. The presence of $\mathrm{CO}$ as a combustion product appeared only at low oxygen carrier to coal ratios. This material has the capacity to generate $\mathrm{O}_{2}$ at lower temperatures than needed
\end{abstract}


Submitted, accepted and published by

International Journal of Greenhouse Gas Control 65 (2017) 76-85

for $\mathrm{Cu}$-based oxygen carriers, which suggests that this material is suitable for work at lower temperatures in a fuel reactor with complete combustion of the fuel. The low attrition rate and attrition index, together with the stable crushing strength of the particles with redox cycles, make this $\mathrm{Cu}-\mathrm{Mn}$ oxygen carrier suitable for operation in a continuous CLOU unit.

Keywords: $\mathrm{CO}_{2}$ capture, coal, CLOU, mixed oxide, copper, manganese

\section{Introduction}

A form of Chemical Looping Combustion (CLC) with $\mathrm{CO}_{2}$ capture as an alternative to the burning of solid fuels is the Chemical Looping with Oxygen Uncoupling (CLOU) process (Mattisson et al., 2009b). The CLOU process requires a material or oxygen carrier with the ability to release gaseous $\mathrm{O}_{2}$ in a determined window of high temperatures $\left(800-1000{ }^{\circ} \mathrm{C}\right)$ in order to be suitable, e.g. copper and manganese oxides. This characteristic is advantageous for the combustion of solid fuel, given that the released $\mathrm{O}_{2}$ burns directly with the fuel. In addition, a CLOU oxygen carrier has to be regenerated in an air reactor after releasing oxygen in the fuel reactor. One of the main advantages of the CLOU process with respect to other CLC technologies that burn solids fuels with $\mathrm{CO}_{2}$ capture is that the direct combustion of char with the $\mathrm{O}_{2}$ generated is much faster than char gasification, e.g. the $i$ G-CLC process (Adánez et al., 2013). The $i \mathrm{G}-\mathrm{CLC}$ process requires a previous gasification step in order to burn the coal or biomass, which is a slow reaction. Moreover, two disadvantages have been detected with $i \mathrm{G}-\mathrm{CLC}$ : the presence of unburnt products in the exit gas stream from the fuel 
Submitted, accepted and published by

International Journal of Greenhouse Gas Control 65 (2017) 76-85

reactor (Gayán et al., 2013), and the transfer of char to the air reactor with the oxygen carrier, the result of incomplete gasification, causing a reduction in $\mathrm{CO}_{2}$ capture efficiency (Cuadrat et al., 2011, 2012). Therefore a carbon stripper is necessary if the unburnt char is to be recirculated to the fuel reactor before reaching the air reactor (Markström et al., 2013).

Three metal oxide systems have been found to have suitable properties for use as oxygen carriers in the CLOU process: $\mathrm{CuO} / \mathrm{Cu}_{2} \mathrm{O}, \mathrm{Mn}_{2} \mathrm{O}_{3} / \mathrm{Mn}_{3} \mathrm{O}_{4}$, and $\mathrm{Co}_{3} \mathrm{O}_{4} / \mathrm{CoO}$ (Mattisson et al., 2009b). Fuel and air reactor operating conditions would be determined as a function of the metal oxide system used and their thermodynamics. Figure 1 shows the partial pressure of $\mathrm{O}_{2}$ as a function of the temperature calculated with HSC Software (Oy, 2008) for the different CLOU metal oxides systems, $\mathrm{CuO} / \mathrm{Cu}_{2} \mathrm{O}, \mathrm{Mn}_{2} \mathrm{O}_{3} / \mathrm{Mn}_{3} \mathrm{O}_{4}$, and $\mathrm{Co}_{3} \mathrm{O}_{4} / \mathrm{CoO}$. Mattisson et al. (2009a) and Eyring et al. (2011) proved that conversion of char by CLOU is much faster than by $i \mathrm{G}-\mathrm{CLC}$ in experiments carried out in a batch fluidized bed reactor with different solid fuels. This fact was confirmed in a CLOU continuous unit burning coals of different rank and biomass using a Cu-based oxygen carrier (Abad et al., 2012; Adánez-Rubio et al., 2014a; Adánez-Rubio et al., 2013a). One of the key characteristics behind the high $\mathrm{CO}_{2}$ capture efficiency produced in these experiments was fast char conversion by combustion with the oxygen released by the oxygen carrier. Furthermore, these experiments achieved complete combustion to $\mathrm{CO}_{2}$ and $\mathrm{H}_{2} \mathrm{O}$, together with excess $\mathrm{O}_{2}$ in at the fuel reactor outlet stream.

A review of proposed CLOU materials was made by Mattisson (2013). This review included a Cu-based oxygen carrier (Adánez-Rubio et al., 2011; Gayán et al., 2012), and the mixed oxide-based oxygen carriers Cu-Mn (Hosseini et al., 2015; Pour et al., 2013) 
Submitted, accepted and published by

International Journal of Greenhouse Gas Control 65 (2017) 76-85

and Mn-Fe and Mn-Si (Ryden et al., 2011). Oxygen carrier particles containing $60 \mathrm{wt} \%$

$\mathrm{CuO}$ and prepared by spray drying were used in a $1.5 \mathrm{~kW}_{\text {th }}$ continuous CLOU unit where a proof of concept for the CLOU process was demonstrated using coal as fuel (Abad et al., 2012). The effect of coal rank, ranging from lignite to anthracite, on the process performance was also analysed (Adánez-Rubio et al., 2013a) in this unit. Encouraging results were also obtained during biomass combustion with this oxygen carrier (Adánez-Rubio et al., 2014a) by means of the CLOU process. The behaviour of this oxygen carrier was completed with the study of the sulphur effect in the $\mathrm{CO}_{2}$ capture efficiency (Adánez-Rubio et al., 2014b), and the solids inventory needed for coal combustion as a function of its reduction/oxidation reactions kinetics (AdánezRubio et al., 2014c). In all the tests performed, the oxygen carrier did not show any decrease in its reactivity, and no agglomeration was found in the bed. However, this oxygen carrier showed an important reduction in the crushing strength of the particles associated with an increase in porosity with operating time. This fact indicates that the lifetime of this oxygen carrier needs to be improved (Adánez-Rubio et al., 2012b). Therefore, a successful CLOU operation requires an oxygen carrier with the following characteristics: high $\mathrm{O}_{2}$ release rate, high reactivity with coal and biomass, and a reduced attrition rate.

Mn-based materials offer some advantages with respect to $\mathrm{Cu}$-based materials as oxygen carriers. It could be possible to operate at lower temperatures because the partial pressure of $\mathrm{O}_{2}$ at equilibrium in the $\mathrm{Mn}_{2} \mathrm{O}_{3} / \mathrm{Mn}_{3} \mathrm{O}_{4}$ system is higher at low temperatures than it is in the copper system. Also, manganese materials are cheaper than copper ones. Nevertheless, the temperatures needed to regenerate the $\mathrm{Mn}_{3} \mathrm{O}_{4}$ to $\mathrm{Mn}_{2} \mathrm{O}_{3}$ must be lower than $815^{\circ} \mathrm{C}$ in the air reactor if a high conversion of the $\mathrm{O}_{2}$ in the air is to be achieved. 
Submitted, accepted and published by

International Journal of Greenhouse Gas Control 65 (2017) 76-85

In fact, it was not possible to oxidize the $\mathrm{Mn}_{3} \mathrm{O}_{4}$ to $\mathrm{Mn}_{2} \mathrm{O}_{3}$ under these conditions (Mei et al., 2015; Shulman et al., 2009; Sundqvist et al., 2015).

In order to take full advantage of the properties of the copper and manganese oxides, research in recet years has focused on the CLOU properties of mixed oxides produced from these metal oxides. One property of these materials is that they can be oxidized at temperatures of up to $900{ }^{\circ} \mathrm{C}$ (Adánez-Rubio et al., 2016; Azad et al., 2013; Hosseini et al., 2015). The characteristics of these materials make them of great interest for the CLOU process, since they can release gaseous oxygen by means of reaction (1) or (2), depending on the $\mathrm{Cu}-\mathrm{Mn}$ spinel formed: $\mathrm{CuMn}_{2} \mathrm{O}_{4}$ (Hosseini et al., 2015) or $\mathrm{Cu}_{1.5} \mathrm{Mn}_{1.5} \mathrm{O}_{4}$ (Adánez-Rubio et al., 2016).

$3 \mathrm{CuMn}_{2} \mathrm{O}_{4} \leftrightarrow 3 \mathrm{CuMnO}_{2}+\mathrm{Mn}_{3} \mathrm{O}_{4}+\mathrm{O}_{2}$

$2 \mathrm{Cu}_{1.5} \mathrm{Mn}_{1.5} \mathrm{O}_{4} \leftrightarrow 3 \mathrm{CuMnO}_{2}+\mathrm{O}_{2}$

Different $\mathrm{Cu}-\mathrm{Mn}$ materials have been tested in recent years. $\mathrm{A} \mathrm{Cu}-\mathrm{Mn}$ oxygen carrier prepared by extrusion with $69.2 \mathrm{wt} \% \mathrm{Mn}_{2} \mathrm{O}_{3}$ and $30.8 \mathrm{wt} \% \mathrm{CuO}$ was evaluated by Azad et al. (2013). This study was conducted in a fluidized bed reactor, during which oxygen carrier showed good reactivity with $\mathrm{CH}_{4}$; however, $\mathrm{CO}$ was found in the exit gas stream. Pour et al. (2013) studied the behaviour of 5 different $\mathrm{Cu}-\mathrm{Mn}$ oxygen carrier comprising $\mathrm{Cu}$ in proportions of between $5 \mathrm{wt} \%$ and $61 \mathrm{wt} \%$. They found that the oxygen carriers were able to release gaseous $\mathrm{O}_{2}$ at temperatures higher than $700{ }^{\circ} \mathrm{C}$ and that $\mathrm{O}_{2}$ release decreased over time. They also found that the oxygen carrier with the better properties for CLOU had a $61 \mathrm{wt} \% \mathrm{Cu}$. Hosseini et al. (2015) analysed four $\mathrm{Cu}$ - 
Submitted, accepted and published by

International Journal of Greenhouse Gas Control 65 (2017) 76-85

Mn oxygen carriers with a $\mathrm{Cu}$ content ranging from $25 \mathrm{wt} \%$ to $75 \mathrm{wt} \%$. They found that the active phase was the spinel $\mathrm{CuMn}_{2} \mathrm{O}_{4}$, and that the $\mathrm{O}_{2}$ concentration released by the oxygen carrier decreased over time. They also found that the oxygen carrier with 25 wt\% $\mathrm{Cu}$ was able to burn coal char completely. Sajen et al. (2016), studied a Cu-Mn oxygen carrier that had been prepared by coprecipitation, calcination for $6 \mathrm{~h}$ at $900{ }^{\circ} \mathrm{C}$ and subsequently pelletizing. They tested $0.2 \mathrm{~g}$ of this oxygen carrier in a fixed bed reactor using syngas as fuel. The active phase detected was $\mathrm{CuMn}_{2} \mathrm{O}_{4}$, and almost complete combustion to $\mathrm{CO}_{2}$ and $\mathrm{H}_{2} \mathrm{O}$ of the syngas was at $800{ }^{\circ} \mathrm{C}$ using around $90 \%$ of the oxygen transport capacity of the oxygen carrier. The oxygen carrier was also regenerated for $3 \mathrm{~h}$ at $900{ }^{\circ} \mathrm{C}$.

Adánez-Rubio et al. (2016) studied a hopcalite-derived oxygen carrier with 29.2 wt\% $\mathrm{CuO}$ and $67.4 \mathrm{wt} \% \mathrm{Mn}_{2} \mathrm{O}_{3}$ that had been calcined for $1 \mathrm{~h}$ at $950{ }^{\circ} \mathrm{C}$. They found that the hopcalite-derived oxygen carried allowed the full conversion of coal in a CLOU process with high rates of oxygen release at temperatures of $900^{\circ} \mathrm{C}$ and lower. However, the particles suffered an important decrease in their crushing strength, with values lower than $1 \mathrm{~N}$ after 30 hours of operation in a batch fluidized bed reactor. This indicated that the material was not suitable for use in the CLOU process unless its physical properties could be improved.

The aim of this work was to develop a suitable $\mathrm{Cu}-\mathrm{Mn}$ based oxygen carrier. Moreover, the development of materials for CLOU applications required the use of industrially scalable methods. Consequently, a new $\mathrm{Cu}-\mathrm{Mn}$ mixed-oxide oxygen carrier was prepared by spray granulation. Fluidized bed granulation, an example of spray granulation, is a particle agglomeration technique of that is very widely used in 
Submitted, accepted and published by

International Journal of Greenhouse Gas Control 65 (2017) 76-85

chemical production, as it is a highly economical and efficient one-pot process.

Fluidization behaviour and the release of gaseous oxygen on attrition rate and

agglomeration problems were analysed in a thermogravimetric analyser (TGA) and in a fluidized bed reactor. The maximum oxygen transfer rates of the oxygen carrier were then determined at different temperatures in a batch fluidized bed reactor with solid fuel addition. A comparison of the properties of this new granulated material was also made against the previously mentioned, commercial hopcalite-derived material.

\section{Experimental}

\subsection{Materials}

\subsubsection{Oxygen carrier}

The material used was a $\mathrm{Cu}-\mathrm{Mn}$ mixed oxide prepared by spray granulation in a spouted bed system (ProCell LabSystem, Glatt). Oxygen carrier particles were prepared at the Instituto de Carboquímica using $\mathrm{Mn}_{3} \mathrm{O}_{4}$ (STREM, PRS) and $\mathrm{CuO}$ (Panreac, PRS) as raw materials. The composition was $34 \mathrm{wt} \% \mathrm{CuO}$ and $66 \mathrm{wt} \% \mathrm{Mn}_{3} \mathrm{O}_{4}$. After particle formation in a spouted lab unit, the particles were calcined for $2 \mathrm{~h}$ at $1125^{\circ} \mathrm{C}$. The $\mathrm{Cu}-$ Mn oxygen carrier particle size was $+0.1-0.3 \mathrm{~mm}$. The oxygen-carrier was given the name of Cu34Mn66-GR.

\subsubsection{Oxygen carrier characterization}

Physical and chemical characterization was carried out on oxygen carrier particles.

Oxygen transport capacity, $R_{O C}$, was determined after the calcination step. Different chemical and physical properties of crushing strength, real density, BET surface area 
Submitted, accepted and published by

International Journal of Greenhouse Gas Control 65 (2017) 76-85

and pore volume were analysed. Further information can be found in (Adánez-Rubio et al., 2012b).

The oxygen carrier attrition resistance was measured using a three-hole air jet attrition tester ATTRI-AS according to the ASTM-D-5757 standard (ASTM, 2011). The weight loss of fines was collected after $1 \mathrm{~h}$ and $5 \mathrm{~h}$ of operation, respectively. Equation (3) shows the Air Jet Index (AJI) value as the percentage of fines after a $5 \mathrm{~h}$ test.

$A J I=\frac{m_{5 h}}{m_{s}}$

where $m_{5 h}$ is the mass of fines after $5 \mathrm{~h}$ collected from the attrition test rig, and $\mathrm{m}_{s}$ the mass of sample loaded into the apparatus (nominally $50 \mathrm{~g}$ ).

X-ray diffraction (XRD) was performed using a Bruker D8 Advance X-ray powder diffractometer and XRD diffractograms obtained. The Joint Committee on Powder Diffraction Standards was used to assign the crystalline phases. DIFFRAC.EVA software supports a reference pattern database derived from the Crystallography Open Database (COD) and The Powder Diffraction File (PDF) for phase identification. Quantitative XRD analysis of the crystalline phase was performed by means of Rietveld refinement using TOPAS software.

The crystalline phase present in the Cu34Mn66-GR carrier could be assigned as either $\mathrm{Cu}_{1.5} \mathrm{Mn}_{1.5} \mathrm{O}_{4}$ or $\mathrm{CuMn}{ }_{2} \mathrm{O}_{4}$ phases, as they both presented a cubic system and space group Fd-3m (227), with slight differences in cell parameter $(8.29 \AA$ and $8.33 \AA$, respectively). However, Rietveld refinement identified the only $\mathrm{Cu}$-containing phase that appropriately fitted the entire diffractogram as $\mathrm{Cu}_{1.5} \mathrm{Mn}_{1.5} \mathrm{O}_{4}$ phase. Separate oxides react to form this main phase during calcination. In keeping with the chemical composition of the hopcalite-derived oxygen carrier (Adánez-Rubio et al., 2016), a 2:1 
Submitted, accepted and published by

International Journal of Greenhouse Gas Control 65 (2017) 76-85

ratio of $\mathrm{Mn}$ to $\mathrm{Cu}$ was used to prepare the Cu34Mn66-GR particles. As the main phase obtained was $\mathrm{Cu}_{1.5} \mathrm{Mn}_{1.5} \mathrm{O}_{4}$, the $\mathrm{Cu}: \mathrm{Mn}$ molar ratio in the active phase was $1: 1$, and thus there was excess $\mathrm{Mn}_{3} \mathrm{O}_{4}$ in the particles. However, this excess reduces oxygen transport capacity in CLOU, owing to difficulties found in regenerating oxygen carriers only containing Mn oxide to $\mathrm{Mn}_{2} \mathrm{O}_{3}$ (Driessens and Rieck, 1967; Mei et al., 2015; Zafar et al., 2007). Therefore, the fresh oxygen carrier particles used in this work have an adjusted composition of $72 \mathrm{wt} \% \mathrm{Cu}_{1.5} \mathrm{Mn}_{1.5} \mathrm{O}_{4}$ and $28 \mathrm{wt} \% \mathrm{Mn}_{3} \mathrm{O}_{4}$, as determined by quantitative XRD analyses.

\subsubsection{Solid fuels}

The fuels used were a Medium Volatile (MV) bituminous South African coal and its char obtained by pyrolysis in a fluidized bed at up to $900^{\circ} \mathrm{C}$ (Adánez-Rubio et al., 2012a). The particle size of the coal and char used in this work was $+200-300 \mu \mathrm{m}$. Table 2 shows the proximate and elemental analyses of the coal and its char.

\subsection{Experimental installations}

\subsubsection{Thermogravimetric Analysis}

Reactivity of the oxygen carrier was analysed in a TGA by multicycles of oxygen uncoupling-oxidation. The TGA, CI Electronics type, is described elsewhere by Adánez et al. (2004).

\section{Data evaluation}

The oxygen carrier conversion from reactivity data obtained in the oxygen uncouplingoxidation cycles in the TGA, was calculated as: 
Submitted, accepted and published by

International Journal of Greenhouse Gas Control 65 (2017) 76-85

Oxygen uncoupling: $\quad X_{\text {Red }}=\frac{m_{O x}-m}{m_{O x}-m_{\text {Red }}}$

Oxidation: $\quad X_{O x}=1-\frac{m_{O x}-m}{m_{O x}-m_{\text {Red }}}$

where $m$ is the sample mass at each time; $m_{O x}$ is the sample mass fully oxidized; and $m_{\text {Red }}$ is the sample mass in the reduced form. The rate of oxygen release was calculated as:

$r_{O_{2}, R e d}=R_{O C} \cdot \frac{\mathrm{d} X_{R e d}}{\mathrm{~d} t}$

\subsubsection{Batch Fluidized Bed Reactor}

Multi-cycles of oxygen uncoupling-oxidation were performed in a fluidized bed reactor in order to determine the oxygen carrier behaviour with regard to oxygen release. These tests also analysed the fluidization behaviour (attrition rate and agglomeration phenomena) of the material. The attrition rate was calculated as:

$v_{\text {attrition }}=\frac{\frac{m_{\text {elut }}}{m_{O C}} * 100}{t} * 3600[\% / h]$

where $v_{\text {attrition }}$ is the attrition rate $(\% / \mathrm{h}) ; m_{\text {elut }}$ is the elutriated mass of oxygen carrier (recovery in pipes and hot filters); $m_{O C}$ is the oxygen carrier total mass in the bed; and $t$ the time of operation. More information on this setup can be found in (Adánez-Rubio et al., 2012b).

\section{Data evaluation}

From the concentration of gaseous oxygen in the exit flow, oxygen carrier conversion can be calculated as a function of time: 
Submitted, accepted and published by

International Journal of Greenhouse Gas Control 65 (2017) 76-85

Oxygen Uncoupling $\quad X_{\text {Red }}(t)=\int_{0}^{t} \frac{F_{O_{2}}}{N_{O_{2}}} d t$

Oxidation

$$
X_{O x}(t)=\int_{0}^{t} \frac{1}{N_{O_{2}}}\left(0.21 F_{\text {air }}-F_{O_{2}}\right) d t
$$

where $X$ is the oxygen carrier conversion; $F_{i}$ is the gas $i$ molar flow rate leaving the reactor; $\mathrm{N}_{\mathrm{O}_{2}}$ are the moles of molecular oxygen which can be released from the fully oxidized oxygen carrier; and $t$ is the time.

\subsubsection{Batch Fluidized Bed Reactor for solid fuels}

In order to determine the release rate of oxygen when fuel combustion and oxygen release were taking place at the same time, multi-cycles of reduction-oxidation were performed using a fluidized bed reactor for solid fuels. For further information on the batch fluidized bed reactor for solid fuels, see (Adánez-Rubio et al., 2012a).

\section{Data evaluation}

A mass balance of the oxygen atoms in the reactor was carried out to calculate the rate of instantaneous oxygen generation per the amount of oxygen carrier (oxygen transfer rate), $r_{O_{2}, R e d}(t)$

$$
r_{O_{2}, \text { Red }}(t)=\frac{M_{\mathrm{O}_{2}}}{m_{O x}}\left[F_{\mathrm{O}_{2}}+F_{\mathrm{CO}_{2}}+0.5\left(F_{C O}+F_{\mathrm{H}_{2} \mathrm{O}}\right)-0.5 F_{O, S F}\right]
$$

The oxygen carrier particles started the reducing period fully oxidized, i.e. $X_{O x}=1$. The degree of oxidation decreased during the reduction reaction. Therefore, the oxidation conversion of the oxygen carrier was calculated by integrating $r_{O_{2}, \text { Red }}$, with time as:

$$
X_{O x}(t)=1-\frac{m_{O x}}{M_{O_{2}} N_{O_{2}}} \int_{t_{0}}^{t} r_{O_{2}, R e d}(t) \mathrm{d} t
$$


Submitted, accepted and published by

International Journal of Greenhouse Gas Control 65 (2017) 76-85

A mass balance of the oxygen in the reactor was carried out in order to calculate the rate of oxidation with the oxygen in the air - Equation (12) - and the oxidation conversion of the oxygen carrier over time, $X_{O x}-$ Equation (13). As there have been cases where the char was not fully burnt during the period of reduction, $\mathrm{CO}_{2}$ and $\mathrm{CO}$ were taken into account during the period of oxidation, due to the combustion of the unburnt char with the oxygen in the air, see Equation (12).

$$
\begin{aligned}
& \left(-r_{O_{2}, O x}(t)\right)=\frac{M_{O_{2}}}{m_{O x}}\left[0.21 F_{\text {air }}-F_{O_{2}}-\left(F_{C_{2}}+0.5 F_{C O}\right)\right] \\
& X_{O x}(t)=X_{f}+\frac{m_{O x}}{M_{O_{2}} N_{O_{2}}} \int_{0}^{t}\left(-r_{O_{2}, O x}(t)\right) \mathrm{d} t
\end{aligned}
$$

\section{Results}

\subsection{Oxygen carrier reactivity in TGA}

Different experiments were performed in a TGA in order to analyse the rates of oxygen release and regeneration of the $\mathrm{Cu}-\mathrm{Mn}$ oxygen carrier. From these experiments, the oxygen transport capacity $\left(R_{O C}\right)$ of the oxygen carrier particles for CLOU reaction was calculated as:

$$
R_{O C}=\frac{m_{O x}-m_{R e d}}{m_{O x}}
$$

Considering the amount active phase in the particles $\left(67 \mathrm{wt} \% \mathrm{Cu}_{1.5} \mathrm{Mn}_{1.5} \mathrm{O}_{4}\right)$, the theoretical oxygen transport capacity of the particles was estimated at $4.3 \mathrm{wt} \%$. However, the result obtained in the TGA showed a real $\mathrm{R}_{\mathrm{OC}}$ of $4.0 \mathrm{wt} \%$. 
Submitted, accepted and published by

International Journal of Greenhouse Gas Control 65 (2017) 76-85

Figures 2 (a), (b) and (c) show oxygen carrier conversion as a function of time at different temperatures, and oxidation at different $\mathrm{O}_{2}$ concentrations. It can be seen that the reduction conversion rate was highly dependent on temperature, increasing when the temperature increased. Thus, maximum conversion was reached in $7 \mathrm{~min}$ at $950^{\circ} \mathrm{C}$. However, only $73 \%$ conversion was reached after 30 min was at $800^{\circ} \mathrm{C}$, see Figure 2 (a). This was due to the simultaneous increase in the kinetic constant and the driving force of the reduction reaction, which was the difference between the equilibrium oxygen concentration released by the oxygen carrier and the inlet concentration, in this case 0 due to the use of pure $\mathrm{N}_{2}$. As seen in Figure 1, the oxygen concentration at equilibrium increased with temperature for pure $\mathrm{Cu}$ and $\mathrm{Mn}$ oxides.

Figure 2(b) shows that the oxidation rate was very fast at all temperatures tested, reaching maximum oxidation conversion in less than $5 \mathrm{~min}$ for each temperature. Therefore, the oxidation reaction was more dependent on oxygen concentration during the oxidation period than on temperature, as shown in Figure 2(c). Note that the maximum oxidation conversion at $800^{\circ} \mathrm{C}$ was the same as that of the final reduction conversion, indicating that during the regeneration step, all the previously released oxygen was regenerated at all the temperatures tested.

\section{2 $\mathrm{N}_{2}$-air cycles in batch fluidized bed reactor}

Multiple oxygen uncoupling-oxidation cycles were carried out in the batch fluidized bed reactor for $\mathrm{N}_{2}$-air cycles at temperatures between $800-900{ }^{\circ} \mathrm{C}$ to analyse the $\mathrm{O}_{2}$ generation by the $\mathrm{Cu}-\mathrm{Mn}$ oxygen carrier. Both attrition rate and agglomeration behaviour were also analysed in these tests. A total of $35 \mathrm{~h}$ fluidization operation was 
Submitted, accepted and published by

International Journal of Greenhouse Gas Control 65 (2017) 76-85

performed, corresponding to 18 oxygen uncoupling-oxidation cycles. Figure 3 shows the $\mathrm{O}_{2}$ generated by the $\mathrm{Cu}-\mathrm{Mn}$ oxygen carrier and measured at the outlet of the batch reactor at $850^{\circ} \mathrm{C}$ for 5 consecutive cycles. It can be seen that the cycles were highly repetitive for both oxygen uncoupling and oxidation reactions. The concentration of oxygen released was observed to decrease over time in the course of the oxygen uncoupling period, from 2 vol\% to 1.4 vol\% $\mathrm{O}_{2}$ in $30 \mathrm{~min}$. Similar behaviour has also been observed with the hopcalite-derived oxygen carrier (Adánez-Rubio et al., 2016) and other Cu-Mn-based oxygen carriers for CLOU (Azad et al., 2013; Hosseini et al., 2015; Pour et al., 2013). It should be pointed out that the concentration of oxygen released by the oxygen carrier was always higher than the $\mathrm{CuO}$ equilibrium concentration but lower than the equilibrium concentration for $\mathrm{Mn}_{2} \mathrm{O}_{3}$. In the case of the oxidation step, oxygen carrier oxidation conversion was initially seen to be very fast; however, when oxidation exceeded $90 \%$, the conversion rate decreased.

In the batch fluidized bed reactor for $\mathrm{N}_{2}$-air cycles, the experiments were conducted at temperatures between 800 and $900^{\circ} \mathrm{C}$. As with the previous CLOU oxygen carriers tested (Adánez-Rubio et al., 2016; Adánez-Rubio et al., 2013b; Adánez-Rubio et al., 2012b; Gayán et al., 2012), the $\mathrm{O}_{2}$ generation rate was restricted by thermodynamic constrains at all temperatures tested. This restriction was more evident at the lowest temperature tested, where the $\mathrm{O}_{2}$ concentration quickly decreased to values below 1 vol\%., see Figure 4. $\mathrm{O}_{2}$ concentrations higher than those corresponding to the $\mathrm{CuO}$ equilibrium at the same temperature were always found $(0.11 \mathrm{vol} \%)$. In all experiments, the $\mathrm{Cu}-\mathrm{Mn}$ oxygen carrier was fully regenerated using 10 vol\% $\mathrm{O}_{2}$ during the oxidation period, and therefore all the $\mathrm{O}_{2}$ released by oxygen uncoupling was recovered. 
Submitted, accepted and published by

International Journal of Greenhouse Gas Control 65 (2017) 76-85

Figure 3 shows that oxygen release varied with time, and, therefore, that the oxygen released was related to oxygen carrier conversion. Figure 4 shows the $\mathrm{O}_{2}$ concentration released as a function of oxygen carrier conversion at three different temperatures $(800$, 850 and $900^{\circ} \mathrm{C}$ ). As can be appreciated, the lower the oxygen carrier conversion, the higher the $\mathrm{O}_{2}$ concentration released. This fact could have a major impact on continuous operation, where oxygen carrier conversion depends directly on the mean residence time of the particles in the fuel reactor, directly affecting combustion and $\mathrm{CO}_{2}$ capture efficiencies.

A key factor for the use of an oxygen carrier in CLOU is its ability to be regenerated in the air reactor, where the $\mathrm{O}_{2}$ concentration varies between the inlet and the outlet. The effect of $\mathrm{O}_{2}$ concentration $(5,10,21 \mathrm{vol} \%)$ during the oxidation step was analysed at $850^{\circ} \mathrm{C}$, see Figure 5. It was observed that by decreasing the $\mathrm{O}_{2}$ concentration, the oxidation rate also decreased, and therefore increasing the time needed to reach full regeneration of the oxygen carrier. This is due to fact that a decrease in the $\mathrm{O}_{2}$ concentration in the oxidation gas stream reduces the driving force (the difference between the oxygen feed and the $\mathrm{O}_{2}$ at equilibrium), thus decreasing the oxidation rate. Consequently, the oxygen carrier is fully regenerated in $10 \mathrm{~min}$ at a concentration of 21 vol $\% \mathrm{O}_{2}$, while $45 \mathrm{~min}$ is required at $10 \mathrm{vol} \% \mathrm{O}_{2}$ and $55 \mathrm{~min}$ at $5 \mathrm{vol} \% \mathrm{O}_{2}$.

Oxygen carrier attrition rates were determined during the $35 \mathrm{~h}$ of oxygen uncouplingoxidation cycles performed in the batch reactor. Figure 6 shows how the attrition rate of the $\mathrm{Cu}-\mathrm{Mn}$ oxygen carrier varied over time. The attrition rate was very low and stable, reaching a final value of $0.005 \% / \mathrm{h}$ after $35 \mathrm{~h}$, which corresponds to a particle lifetime 
Submitted, accepted and published by

International Journal of Greenhouse Gas Control 65 (2017) 76-85

of $20000 \mathrm{~h}$. This attrition rate value is 18 times lower than that obtained in the same setup using a hopcalite-derived oxygen carrier (Adánez-Rubio et al., 2016).

\subsection{Effect of the oxygen carrier to fuel ratio during batch fluidized bed reactor cycles with coal and char}

In order to obtain high combustion and $\mathrm{CO}_{2}$ capture efficiencies in the CLOU process, there are two keys parameters: char conversion rate and oxygen carrier reactivity. The coal fed into the fuel reactor undergoes a devolatilization process in which combustion efficiency depends directly on the conversion of this volatile matter into $\mathrm{CO}_{2}$ and $\mathrm{H}_{2} \mathrm{O}$, which is determined by oxygen carrier reactivity (by CLOU or CLC reactions (AdánezRubio et al., 2016)). On the other hand, $\mathrm{CO}_{2}$ capture efficiency depends on the char conversion rate. In this case, the char conversion rate depends on the char and oxygen carrier reactivities, and therefore on the fuel type and the characteristics of the oxygen carrier.

In order to determine the solid fuel conversion performance of the oxygen carrier, several combustion-oxidation cycles were carried out in the batch fluidized bed reactor for solid fuels using coal or its char as fuel. Experiments conducted with char as fuel were for the purpose of analysing char combustion separately from volatiles combustion. In order to determine the rate of maximum oxygen generation by the carrier and the char combustion rate, several tests were performed by modifying the oxygen carrier to fuel ratio according to the methodology proposed by Adánez-Rubio et al. (2012a). Two different series were conducted with char while varying the oxygen carrier concentration, and one with coal. The first series with char was carried out with 
Submitted, accepted and published by

International Journal of Greenhouse Gas Control 65 (2017) 76-85

the bed filled only with the $\mathrm{Cu}-\mathrm{Mn}$ oxygen carrier (100 wt\%). Subsequent experiments

- the second char series and with coal as fuel - had the $\mathrm{Cu}-\mathrm{Mn}$ oxygen carrier diluted to

$2.5 \mathrm{wt} \%$ in alumina in order to decrease the oxygen carrier to carbon ratio. The bed

mass of oxygen carrier + alumina was $0.3 \mathrm{~kg}$ in all the tests. A total of $45 \mathrm{~h}$ operation

with $100 \mathrm{wt} \%$ oxygen carrier, corresponding to 27 cycles of combustion-oxidation, and

$70 \mathrm{~h}$ operation with $2.5 \mathrm{wt} \%$ oxygen carrier, corresponding to 80 cycles of combustion-

oxidation were performed. The temperature interval was $800-900{ }^{\circ} \mathrm{C}$. No agglomeration problems were detected during this experimental study, regardless of the degree of reduction achieved by the oxygen carrier during combustion.

Figure 7 shows the measured concentration of the different gaseous compounds $\left(\mathrm{O}_{2}\right.$, $\mathrm{CO}_{2}, \mathrm{CO}, \mathrm{H}_{2}$ and $\left.\mathrm{CH}_{4}\right)$ in the exit stream of the batch fluidized bed reactor during a combustion-oxidation cycle at $850^{\circ} \mathrm{C}$ while burning a 2-g batch of char. $\mathrm{N}_{2}$ was used as a fluidization agent during the reduction period and a mixture $\left(\mathrm{N}_{2} /\right.$ air $)$ with 10 vol\% $\mathrm{O}_{2}$ was used during oxidation (considering this to be the average $\mathrm{O}_{2}$ concentration in a fluidized bed reactor with plug flow for gases and reaction order 1). At time $t=0$ the reduction period started commenced by fluidizing with $\mathrm{N}_{2}$, after which the $\mathrm{Cu}-\mathrm{Mn}$ oxygen carrier began to generate gaseous $\mathrm{O}_{2}$; after a couple of minutes, the batch of char $(2 \mathrm{~g})$ was added to the bed. The $\mathrm{O}_{2}$ released by the oxygen carrier led to the rapid combustion of the char. The bed temperature underwent a rapid increase due to the exothermic char combustion,. Only $\mathrm{CO}_{2}$ and $\mathrm{O}_{2}$ were found at the gas outlet; hence the char was completely burned to $\mathrm{CO}_{2}$ and $\mathrm{H}_{2} \mathrm{O}$, with no residual unburnt products. The maximum $\mathrm{CO}_{2}$ concentration reached was 22 vol\% for 5 second, then decreasing. Char combustion was characterized by a sharp increase followed by a long decrease in the 
Submitted, accepted and published by

International Journal of Greenhouse Gas Control 65 (2017) 76-85

$\mathrm{CO}_{2}$ concentration in the bed. Char combustion was complete when the $\mathrm{CO}_{2}$ concentration fell to zero.

During the reduction period, the oxygen carrier was able to generate enough oxygen and at at a sufficiently fast rate to burn the char and also remain as $\mathrm{O}_{2}(\mathrm{~g})$ in the gas outlet stream. Nevertheless, the $\mathrm{O}_{2}$ concentration decreased from 2 vol\% to $0.4 \mathrm{vol} \%$ during char combustion, but the oxygen carrier continued to release $\mathrm{O}_{2}$ until the oxidation period started. This decrease in the concentration of $\mathrm{O}_{2}$ released was also observed, although more gradually, in the experiments performed without combustion, see Section 3.2.

It was observed that the biggest reduction in the conversion rate of the $\mathrm{Cu}-\mathrm{Mn}$ oxygen carrier occurred when the oxygen carrier burnt the char fed to the bed, owing to the fast oxygen transfer from the oxygen carrier to the char. After char combustion was complete, the $\mathrm{Cu}-\mathrm{Mn}$ oxygen carrier continued to release gaseous oxygen because the oxygen carrier had not reached maximum conversion after the char combustion. An oxidation conversion of $46 \%$ was achieved during the reduction period.

The oxygen carrier oxidation conversion during the redox cycle can be also seen in Figure 7 . The oxidation period started at $\mathrm{t}=35 \mathrm{~min}$, after which bed temperatures increased quickly due to the exothermic nature of the regeneration reaction. A shoulder in oxygen concentration was noticed during the oxidation period, between minutes 40 and 45, an effect that might have been due to the formation of an intermediate phase $\mathrm{Cu}_{1.7} \mathrm{Mn}_{1.3} \mathrm{O}_{3}$ (Driessens and Rieck, 1967) which is later oxidized to $\mathrm{Cu}_{1.5} \mathrm{Mn}_{1.5} \mathrm{O}_{4}$. The oxygen carrier was fully oxidized within $30 \mathrm{~min}$. 
Submitted, accepted and published by

International Journal of Greenhouse Gas Control 65 (2017) 76-85

In order to study the oxygen transfer rate, different experiments were performed in which the char load was varied between 0.5 and $2 \mathrm{~g}$. These values corresponded to oxygen carrier to char ratios between 125 and 550. No unburnt products were detected in any of these tests; only $\mathrm{CO}_{2}$ and $\mathrm{O}_{2}$ were measured. On the other hand, the $\mathrm{CO}_{2}$ concentration increased when the mass of char fed to the bed was increased. This indicates an increase in the amount of char burnt in the bed. Furthermore, more oxygen was transferred from the oxygen carrier to the gas products. These results agree with the results obtained by Adánez-Rubio et al. (2016), with a hopcalite-derived oxygen carrier, for which no unburnt products were found during char combustion in a batch fluidized bed reactor. On the contrary, Azad et al. (2013) found $\mathrm{CO}$ and $\mathrm{CH}_{4}$ as combustion products using a $\mathrm{Cu}-\mathrm{Mn}$ oxygen carrier in a batch fluidized bed reactor. The absence of unburnt products indicates the high oxygen transfer rate together with the high oxygen transport capacity of the $\mathrm{Cu}-\mathrm{Mn}$ oxygen carrier evaluated in this work.

The char reacts directly with the gaseous $\mathrm{O}_{2}$ released by the oxygen carrier in this process, and its rate depends on the oxygen transfer rate. As shown by the Equation (10), the instantaneous oxygen transfer rate, $r_{O_{2}, \text { red }}$,can be calculated from the evolution of gas concentration in the exit stream $\left(\mathrm{CO}_{2}\right.$ and $\left.\mathrm{O}_{2}\right)$. Figure 8 shows the instantaneous oxygen generation rate as a function of the oxygen carrier to char ratio. The maximum oxygen generation rate was not reached in the experiments carried out with $100 \mathrm{wt} \%$ oxygen carrier in the bed, because when more char was fed to the bed, the $\mathrm{Cu}-\mathrm{Mn}$ oxygen carrier released more oxygen . Therefore, the oxygen generation rate depends more on the char fed than on the $\mathrm{Cu}-\mathrm{Mn}$ oxygen carrier reactivity. Thus, decreasing the oxygen carrier to char ratio allows the oxygen generation rate to increase. 
Submitted, accepted and published by

International Journal of Greenhouse Gas Control 65 (2017) 76-85

A second experimental series was carried out in order to determine the maximum oxygen transfer rate. In order to decrease the oxygen carrier to char ratio, the amount of oxygen carrier in the bed was decreased from $100 \mathrm{wt} \%$ to $2.5 \mathrm{wt} \%$ by diluting the oxygen carrier with alumina. The char mass used in this series of experiments varied between $0.05 \mathrm{~g}$ and $1 \mathrm{~g}$, corresponding to oxygen carrier to char ratios between 140 and 9. In these experiments, with ratios lower than 16, no gaseous oxygen appeared; however, no unburnt products $\left(\mathrm{CO}, \mathrm{CH}_{4}\right.$ or $\left.\mathrm{H}_{2}\right)$ were found. This trend is seen to be similar to that found with other CLOU oxygen carriers tested at a similar oxygen carrier to char ratio of (Adánez-Rubio et al., 2016; Adánez-Rubio et al., 2012a). For oxygen carrier to char ratio values above 30 , a decrease in the ratio would cause an increase in the oxygen generation rate. On the other hand, for values below 30, oxygen carrier generation remained constant even when the oxygen carrier to char ratio decreased; thus, the maximum value of oxygen generation rate was obtained. For oxygen carrier to char ratios lower than 30, only oxygen carrier reactivity determined oxygen generation rate. When the fuel was fed into the bed, the temperature inside the bed increased by around $30^{\circ} \mathrm{C}$, so if the initial temperature was $\mathrm{T}_{0}=850^{\circ} \mathrm{C}$, then temperature was $\mathrm{T}_{\max }=$ $880^{\circ} \mathrm{C}$ when maximum oxygen generation rate was reached. Thus, at $\mathrm{T}_{\max }=880{ }^{\circ} \mathrm{C}$, the maximum oxygen transfer rate was $0.18 \times 10^{-3} \mathrm{~kg} \mathrm{O}_{2} / \mathrm{s}$ per $\mathrm{kg}$ of oxygen carrier. Table 3 shows the maximum oxygen transfer rate values obtained at different temperatures. It can be observed that an increase in the reaction temperature in the bed increased the maximum oxygen generation rate from $0.08 \times 10^{-3}\left(\mathrm{~T}_{\max }=830^{\circ} \mathrm{C}\right)$ to $0.25 \times 10^{-3}\left(\mathrm{~T}_{\max }=\right.$ $930^{\circ} \mathrm{C}$ ). It can be seen that the biggest increment occurred between $830^{\circ} \mathrm{C}$ and $855^{\circ} \mathrm{C}$, when the maximum oxygen transfer rate was doubled with an increase of $25^{\circ} \mathrm{C}$ in the reaction rate. This improvement can be important in a CLOU process. Also in Table 3, 
Submitted, accepted and published by

International Journal of Greenhouse Gas Control 65 (2017) 76-85

it can be seen that the maximum oxygen generation values for Cu34Mn66-GR are

slightly lower than those obtained for a hopcalite-derived oxygen carrier analysed at the same temperatures.

Although a maximum oxygen transfer rate was found when using char, it was necessary to know the behaviour of the oxygen carrier in the presence of volatiles in the fuel when using coal. Therefore, a second series was performed with $2.5 \mathrm{wt} \%$ oxygen carrier in the bed in order to analyse the combustion of coal by the oxygen carrier in the batch reactor. The interval of oxygen carrier to coal ratios analysed in this series was between 180 and 8. As was found in the experiments performed with char, there was $\mathrm{O}_{2}$ in the outlet gases at high oxygen carrier to coal ratios. However, for ratios below 140, the $\mathrm{O}_{2}$ fell to zero during combustion. Moreover, with oxygen carrier to coal ratio values lower than 140, CO appeared in the gas exit stream from the batch reactor. Also, with ratios lower than 140 unburnt char remained in the bed at the end of the reduction period. This unconverted char was burnt during the oxidation step. According to CLOU reaction stoichiometry and ultimate analysis of coal, an oxygen carrier to fuel ratio of 49 is sufficient for the complete combustion to $\mathrm{CO}_{2}$ and $\mathrm{H}_{2} \mathrm{O}$. Therefore, for ratios between 140 and 49, there was enough oxygen in the oxygen carrier to completely burn the fuel char. Nevertheless, the oxygen carrier transfer rate was not high enough to convert it. Moreover, the absence of gaseous $\mathrm{O}_{2}$ in the outlet gases together with the presence of $\mathrm{CO}$ indicates that all the gaseous oxygen released by the oxygen carrier was consumed to burn the volatiles, but that part of the $\mathrm{CO}$ did not have a long enough residence time in the bed to be fully converted. 
Submitted, accepted and published by

International Journal of Greenhouse Gas Control 65 (2017) 76-85

Figure 9 shows that when the oxygen carrier to coal ratio was decreased, the oxygen generation rate would increase. Contrary to what was found when char was used as fuel, the maximum generation rate was not reached with coal, and whenever the oxygen carrier to coal ratio was decreased, the oxygen generation rate always increased. This behaviour was also found when using a hopcalite-derived oxygen carrier (AdánezRubio et al., 2016). With ratios below 11, oxygen carrier reduction conversion for CLOU exceeded $100 \%$ after burning the fed coal and keeping part of the coal char unburnt, while some char remained unburnt in the bed.

Figure 9 also shows the difference in oxygen generation rates when burning coal and char. At high oxygen carrier to fuel ratios, above 140, oxygen generation rate was similar for both fuels. However, when the ratio decreased, the difference between both oxygen transfer rates increased, reaching values 8 times higher for coal than for char. At low ratios, there was no $\mathrm{O}_{2}$ in the outlet gases, but $\mathrm{CO}$ from volatiles was present in the case of coal. This big difference between the combustion of coal or its char was also detected by Adánez-Rubio et al. (2016) with a hopcalite-derived oxygen carrier. This difference is attributed to the different reactions that could be taking place inside the bed. Char combustion is produced by the reaction with the $\mathrm{O}_{2}$ generated by the oxygen carrier, see Equation (2). However, the combustion of volatiles can be produced either by gaseous $\mathrm{O}_{2}$ or by direct combustion with the oxygen carrier or CLC reaction. Equations (15) and (16) show the CLC reaction of volatiles with the oxygen carrier $\left(\mathrm{Cu}_{1.5} \mathrm{Mn}_{1.5} \mathrm{O}_{4}\right)$. The higher oxygen transfer rates of the carrier with coal can be explained by means of these reactions. 
Submitted, accepted and published by

International Journal of Greenhouse Gas Control 65 (2017) 76-85

$2 \mathrm{Cu}_{1.5} \mathrm{Mn}_{1.5} \mathrm{O}_{4}+\mathrm{CO}+\mathrm{H}_{2} \leftrightarrows 3 \mathrm{CuMnO}_{2}+\mathrm{CO}_{2}+\mathrm{H}_{2} \mathrm{O}$

$2 \mathrm{Cu}_{1.5} \mathrm{Mn}_{1.5} \mathrm{O}_{4}+3 \mathrm{CO}+2 \mathrm{H}_{2} \leftrightarrows 3 \mathrm{Cu}+3 \mathrm{MnO}+3 \mathrm{CO}_{2}+2 \mathrm{H}_{2} \mathrm{O}$

When oxygen carrier conversion for CLOU is $\leq 100 \%$, Equation (15) likely describes the oxygen carrier reduction by the volatiles. Nevertheless, with oxygen carrier to coal ratios lower than 11 , the mass balance of the oxygen interchange shows that the oxygen carrier reduction was higher than $100 \%$. This can occur if the oxygen carrier decomposes to $\mathrm{Cu}^{0}$ and $\mathrm{MnO}$ by CLC reaction, see Equation (16). Even under these conditions, no agglomeration was observed in the reactor. In view of results found, the CLC reaction between the volatiles and the oxygen carrier is faster than the $\mathrm{O}_{2}$ release reaction. The presence of $\mathrm{CO}$ as an unburnt product in the gas outlet stream indicates that it is necessary to use oxygen carrier to coal ratios higher than 140 to burn fuels with high amounts of volatile matter in their composition.

Finally, the results obtained in this study for Cu34M66-GR oxygen carrier can be compared to the results from the study of a hopcalite-derived oxygen carrier obtained by Adánez-Rubio et al. (2016) using the same coal. It can be seen that hopcalite-derived oxygen carrier showed a higher oxygen transfer rate in the entire range of oxygen carrier to coal ratios studied. The hopcalite oxygen carrier rate is around 2.5 times higher than that shown by the Cu34Mn66-GR oxygen carrier. However, the low attrition rate shown by the Cu34M66-GR oxygen carrier and the complete combustion of the fuel with oxygen carrier to coal ratios higher than 140 makes this material a good candidate for use as an oxygen carrier for the CLOU process. 
Submitted, accepted and published by

International Journal of Greenhouse Gas Control 65 (2017) 76-85

\subsection{Characterization of used oxygen carrier particles}

Samples of the $\mathrm{Cu}-\mathrm{Mn}$ oxygen carrier, both fresh and used in both batch reactors, were characterized using different techniques. The main characteristics of the different samples are presented in Table 1. It can be seen that the porosity of the sample decreased slightly, from 12 to $10.8 \%$, as did the crushing strength of the particles, from 1.9 to 1.3 , but the other characteristics remained constant. In order to determine the attrition resistance of the particles, samples of the fresh and used oxygen carrier were subjected to the ASTM standard D5757 method (ASTM, 2011). The fresh Cu34Mn66GR particles showed an AJI value of $3 \%$ after $35 \mathrm{~h}$ of operation in the batch fluidized bed reactor for gaseous fuels; the AJI value was almost constant, with a value of $3.2 \%$, see Table 1. A slight increase of up to $4.2 \%$ was found after $45 \mathrm{~h}$. However, the AJI values remained lower than $5 \%$, which is considered a reference value for the selection of a scalable material (Cabello et al., 2016). Moreover, the attrition rate (shown in Figure 6) and the crushing strength found in the used particles were of suitable values (see Table 1), allowing the conclusion to be made that these particles can be tested in a continuous CLOU unit.

The XRD analysis shows that the main phase in the particles, both fresh and used, was $\mathrm{Cu}_{1.5} \mathrm{Mn}_{1.5} \mathrm{O}_{4}$ with free $\mathrm{Mn}_{3} \mathrm{O}_{4}$. The only chemical difference comes from the presence of $\mathrm{Mn}_{2} \mathrm{O}_{3}$ in the particles used in the batch fluidized bed for solid fuels.

The reactivity of fresh oxygen carrier and used samples after $35 \mathrm{~h}$ in the batch fluidized bed reactor for gaseous fuels and $45 \mathrm{~h}$ in the batch fluidized bed reactor for solids fuels was determined at $950{ }^{\circ} \mathrm{C}$ in the TGA, with $\mathrm{N}_{2}$ used during the reduction and air for 
Submitted, accepted and published by

International Journal of Greenhouse Gas Control 65 (2017) 76-85

oxidation. Figure 10 shows the oxygen carrier conversion curves as a function of time for the oxygen release period for the different used samples and for the initial oxygen carrier. Reactivity was seen to be very similar in both fresh and used oxygen carrier particles of the Cu34Mn66-GR oxygen carrier. This justifies the capacity of the oxygen carrier particles to be used in the CLOU continuous unit, since their reactivity was maintained throughout a lengthy period of redox cycles.

SEM images of fresh and used particles are shown in Figure 11. It can be observed that a granular shape appeared in the surface of the particles after use, see Figure 11 (c, f, i). This granulation was enhanced during the experiments carried out in the batch fluidized bed reactor for solid fuels due to the increase in the reduction conversion of the particles, compare Figure 11(f) and Figure 11(i). This behaviour was previously seen when ilmenite was activated with operation time (Adánez et al., 2010).

\section{Conclusions}

A new $\mathrm{Cu}-\mathrm{Mn}$ oxygen carrier $\left(34 \mathrm{wt} \% \mathrm{CuO}\right.$ and $66 \mathrm{wt} \% \mathrm{Mn}_{3} \mathrm{O}_{4}$ ) prepared by spray granulation was evaluated for CLOU process as oxygen carrier. The oxygen release rate, the agglomeration resistance and the attrition rate were tested in a TGA and in two batch fluidized bed reactors using a South African MV bituminous coal and its char.

Gaseous oxygen generation by the oxygen carrier under fuel reactor conditions was analysed at different temperatures between 800 and $900{ }^{\circ} \mathrm{C}$, with oxygen carrier reactivity maintained throughout the redox cycles performed. No agglomeration was 
Submitted, accepted and published by

International Journal of Greenhouse Gas Control 65 (2017) 76-85

detected in the bed during the experimental study. The oxygen concentration released by the oxygen carrier varied with oxygen carrier conversion, and gave intermediate values between $\mathrm{Mn}_{2} \mathrm{O}_{3} / \mathrm{Mn}_{3} \mathrm{O}_{4}$ and $\mathrm{CuO} / \mathrm{Cu}_{2} \mathrm{O}$ oxygen equilibrium concentration.

In the experiments with char, a decrease in the oxygen carrier to char ratio resulted in an increase in the oxygen transfer rate until it reached a maximum. The maximum transfer rates achieved with char were $0.08 \cdot 10^{-3}$ at $830^{\circ} \mathrm{C}$ and $0.25 \cdot 10^{-3} \mathrm{~kg} \mathrm{O}_{2} / \mathrm{s}$ per $\mathrm{kg}$ of oxygen carrier at $930^{\circ} \mathrm{C}$. The oxygen transfer rate obtained with char as a fuel indicated the rate of oxygen release by the CLOU reaction.

For of oxygen carrier to fuel ratios above 140, the oxygen transfer rate was similar for both coal and char. However, when the ratio decreased, the difference between both oxygen transference rates increased, reaching values 8 times higher for coal than for char. At low ratios, there was not $\mathrm{O}_{2}$ in the outlet gases; and $\mathrm{CO}$ was present when coal was used as fuel. Unlike when char was used as fuel, no maximum transference rate was reached with coal. Whenever the oxygen carrier to coal ratio was decreased, the oxygen transfer rate increased. When the amount of coal fed into the bed was increased, the oxygen was transferred more quickly from the oxygen carrier to the fuel. On the other hand, using coal as fuel involved a faster direct reduction reaction between $\mathrm{Cu}_{1.5} \mathrm{Mn}_{1.5} \mathrm{O}_{4}$ and the volatile matter in the coal.

The results obtained indicate that this $\mathrm{Cu}-\mathrm{Mn}$ oxygen carrier is suitable for coal combustion by the CLOU process, allowing complete conversion of the solid fuel to be achieved with low oxygen carrier to coal ratios. Moreover, the low attrition rate and AJI 
Submitted, accepted and published by

International Journal of Greenhouse Gas Control 65 (2017) 76-85

value, together with a stable particle crushing strength, make this $\mathrm{Cu}-\mathrm{Mn}$ oxygen carrier

suitable for operation in a continuous CLOU unit.

\section{Acknowledgements}

This work was supported by the Spanish Ministry of Economy and Competitiveness (MINECO Project: ENE2013-45454-R) and the European Union FEDER funds.

\section{References}

Abad, A., Adánez-Rubio, I., Gayán, P., García-Labiano, F., de Diego, L., Adánez, J., 2012. Demonstration of chemical-looping with oxygen uncoupling (CLOU) process in a $1.5 \mathrm{~kW}_{\text {th }}$ continuously operating unit using a $\mathrm{Cu}$-based oxygen-carrier. International Journal of Greenhouse Gas Control 6, 189-200.

Adánez-Rubio, I., Abad, A., Gayán, P., Adánez, I., De Diego, L.F., García-Labiano, F., Adánez, J., 2016. Use of Hopcalite-Derived Cu-Mn Mixed Oxide as Oxygen Carrier for Chemical Looping with Oxygen Uncoupling Process. Energy Fuels 30, 5953-5963.

Adánez-Rubio, I., Abad, A., Gayán, P., de Diego, L., García Labiano, F., Adánez, J., 2012a. Identification of operational regions in the Chemical-Looping with Oxygen Uncoupling (CLOU) process with a Cu-based oxygen carrier. Fuel 102, 634-645.

Adánez-Rubio, I., Abad, A., Gayán, P., de Diego, L.F., García-Labiano, F., Adánez, J., 2014a. Biomass combustion with $\mathrm{CO}_{2}$ capture by chemical looping with oxygen uncoupling (CLOU). Fuel Process. Technol. 124, 104-114.

Adánez-Rubio, I., Abad, A., Gayán, P., de Diego, L.F., García Labiano, F., Adánez, J., 2013a. Performance of CLOU process in the combustion of different types of coal with $\mathrm{CO}_{2}$ capture. International Journal of Greenhouse Gas Control 12, 430-440.

Adánez-Rubio, I., Abad, A., Gayán, P., García Labiano, F., de Diego, L., Adánez, J., 2014b. The fate of sulphur in the Cu-based Chemical Looping with Oxygen Uncoupling (CLOU) Process. Appl. Energy 113, 1855-1862. 
Submitted, accepted and published by

International Journal of Greenhouse Gas Control 65 (2017) 76-85

Adánez-Rubio, I., Arjmand, M., Leion, H., Gayán, P., Abad, A., Mattisson, T., Lyngfelt, A., 2013b. Investigation of Combined Supports for Cu-Based Oxygen

Carriers for Chemical-Looping with Oxygen Uncoupling (CLOU). Energy Fuels 27, 3918-3927.

Adánez-Rubio, I., Gayán, P., Abad, A., de Diego, L., García Labiano, F., Adánez, J., 2012b. Evaluation of a Spray-Dried $\mathrm{CuO} / \mathrm{MgAl}_{2} \mathrm{O}_{4} \mathrm{Oxygen}$ Carrier for the Chemical Looping with Oxygen Uncoupling Process. Energy Fuels 26, 3069-3081.

Adánez-Rubio, I., Gayán, P., Abad, A., García-Labiano, F., de Diego, L.F., Adánez, J., 2014c. Kinetic analysis of a Cu-based oxygen carrier: Relevance of temperature and oxygen partial pressure on reduction and oxidation reactions rates in Chemical Looping with Oxygen Uncoupling (CLOU). Chem. Eng. J. 256, 69-84.

Adánez-Rubio, I., Gayán, P., García-Labiano, F., de Diego, L., Adánez, J., Abad, A., 2011. Development of CuO-based oxygen-carrier materials suitable for ChemicalLooping with Oxygen Uncoupling (CLOU) process. Energy Procedia 4, 417-424.

Adánez, J., Cuadrat, A., Abad, A., Gayán, P., Diego, L.F.D., García-Labiano, F., 2010. Ilmenite activation during consecutive redox cycles in chemical-looping combustion. Energy Fuels 24, 1402-1413.

Adánez, J., De Diego, L.F., García-Labiano, F., Gayán, P., Abad, A., Palacios, J.M., 2004. Selection of oxygen carriers for chemical-looping combustion. Energy Fuels 18, 371-377.

Adánez, J., Gayán, P., Adánez-Rubio, I., Cuadrat, A., Mendiara, T., Abad, A., GarcíaLabiano, F., de Diego, L.F., 2013. Use of Chemical-Looping processes for coal combustion with $\mathrm{CO}_{2}$ capture, Energy Procedia, 540-549.

ASTM, 2011. Standard test method for determination of attrition and abrasion of powdered catalyst by air jets. Standard Test Method for Determination of Attrition and Abrasion of Powdered Catalysts by Air Jets.

Azad, A.-M., Hedayati, A., Rydén, M., Leion, H., Mattisson, T., 2013. Examining the $\mathrm{Cu}-\mathrm{Mn}-\mathrm{O}$ Spinel System as an Oxygen Carrier in Chemical Looping Combustion. Energy Technology 1, 59-69. 
Submitted, accepted and published by

International Journal of Greenhouse Gas Control 65 (2017) 76-85

Cabello, A., Gayán, P., García-Labiano, F., De Diego, L.F., Abad, A., Adánez, J., 2016.

On the attrition evaluation of oxygen carriers in Chemical Looping Combustion. Fuel

Process. Technol. 148, 188-197.

Cuadrat, A., Abad, A., García-Labiano, F., Gayán, P., de Diego, L.F., Adánez, J., 2011. The use of ilmenite as oxygen-carrier in a $500 \mathrm{~W}_{\text {th }}$ Chemical-Looping Coal Combustion unit. International Journal of Greenhouse Gas Control 5, 1630-1642.

Cuadrat, A., Abad, A., García-Labiano, F., Gayán, P., de Diego, L.F., Adánez, J., 2012. Relevance of the coal rank on the performance of the in situ gasification chemicallooping combustion. Chem. Eng. J. 195-196, 91-102.

Driessens, F.C.M., Rieck, G.D., 1967. Phase Equilibria in the System Cu-Mn-O. Z. Anorg. Allg. Chem. 351.

Eyring, E.M., Konya, G., Lighty, J.S., Sahir, A.H., Sarofim, A.F., Whitty, K., 2011. Chemical Looping with Copper Oxide as Carrier and Coal as Fuel. Oil Gas Sci.

Technol. 66, 209-221.

Gayán, P., Abad, A., de Diego, L.F., García-Labiano, F., Adánez, J., 2013. Assessment of technological solutions for improving chemical looping combustion of solid fuels with $\mathrm{CO}_{2}$ capture. Chem. Eng. J. 233, 56-69.

Gayán, P., Adánez-Rubio, I., Abad, A., de Diego, L., García Labiano, F., Adánez, J., 2012. Development of $\mathrm{Cu}$-based oxygen carriers for Chemical-Looping with Oxygen Uncoupling (CLOU) process. Fuel 96, 226-238.

Hosseini, D., Imtiaz, Q., Abdala, P.M., Yoon, S., Kierzkowska, A.M., Weidenkaff, A., Müller, C.R., 2015. $\mathrm{CuO}$ promoted $\mathrm{Mn}_{2} \mathrm{O}_{3}$-based materials for solid fuel combustion with inherent $\mathrm{CO}_{2}$ capture. Journal of Materials Chemistry A 3, 10545-10550.

Markström, P., Linderholm, C., Lyngfelt, A., 2013. Chemical-looping combustion of solid fuels - Design and operation of a $100 \mathrm{~kW}$ unit with bituminous coal. International Journal of Greenhouse Gas Control 15, 150-162.

Mattisson, T., 2013. Materials for Chemical-Looping with Oxygen Uncoupling. ISRN Chemical Engineering 2013, 19. 
Submitted, accepted and published by

International Journal of Greenhouse Gas Control 65 (2017) 76-85

Mattisson, T., Leion, H., Lyngfelt, A., 2009a. Chemical-looping with oxygen uncoupling using $\mathrm{CuO} / \mathrm{ZrO}_{2}$ with petroleum coke. Fuel 88, 683-690.

Mattisson, T., Lyngfelt, A., Leion, H., 2009b. Chemical-looping with oxygen uncoupling for combustion of solid fuels. International Journal of Greenhouse Gas Control 3, 11-19.

Mei, D., Mendiara, T., Abad, A., De Diego, L.F., García-Labiano, F., Gayán, P., Adánez, J., Zhao, H., 2015. Evaluation of Manganese Minerals for Chemical Looping Combustion. Energy Fuels 29, 6605-6615.

Oy, O.R., 2008. HSC Chemistry 6.1. Chemical reaction and equilibrium software with thermochemical database and simulation module.

Pour, N., Leion, H., Rydén, M., Mattisson, T., 2013. Combined Cu/Mn oxides as an oxygen carrier in chemical looping with oxygen uncoupling (CLOU). Energy Fuels 27, 6031-6039.

Ryden, M., Rydén, M., Lyngfelt, A., Mattisson, T., 2011. Combined manganese/iron oxides as oxygen carrier for chemical looping combustion with oxygen uncoupling (CLOU) in a circulating fluidized bed reactor system. Energy Procedia 4, 341-348.

Sajen, S., Singh, S.K., Mungse, P., Rayalu, S., Watanabe, K., Saravanan, G., Labhasetwar, N., 2016. Mechanically stable mixed metal oxide of $\mathrm{Cu}$ and $\mathrm{Mn}$ as oxygen carrier for chemical looping syngas combustion. Energy Fuels 30, 7596-7603.

Shulman, A., Cleverstam, E., Mattisson, T., Lyngfelt, A., 2009. Manganese/Iron, Manganese/Nickel, and Manganese/Silicon Oxides Used in Chemical-Looping With Oxygen Uncoupling (CLOU) for Combustion of Methane. Energy Fuels 23, 5269-5275.

Sundqvist, S., Arjmand, M., Mattisson, T., Rydén, M., Lyngfelt, A., 2015. Screening of different manganese ores for chemical-looping combustion (CLC) and chemical-looping with oxygen uncoupling (CLOU). International Journal of Greenhouse Gas Control 43, 179-188. 
Submitted, accepted and published by

International Journal of Greenhouse Gas Control 65 (2017) 76-85

Zafar, Q., Abad, A., Mattisson, T., Gevert, B., Strand, M., 2007. Reduction and oxidation kinetics of $\mathrm{Mn}_{3} \mathrm{O}_{4} / \mathrm{Mg}-\mathrm{ZrO}_{2}$ oxygen carrier particles for chemical-looping combustion. Chem. Eng. Sci. 62, 6556-6567. 
Submitted, accepted and published by

International Journal of Greenhouse Gas Control 65 (2017) 76-85

\section{Nomenclature}

$F_{\text {air }} \quad$ molar flow rate of air $(\mathrm{mol} / \mathrm{s})$

$F_{i} \quad$ molar flow rate of gas $i(\mathrm{~mol} / \mathrm{s})$

$F_{O, S F}$ molar flow rate of oxygen from the existing oxygen in the solid fuel (mol/s)

$m \quad$ mass of sample at each time $(\mathrm{kg})$

$m_{\text {char }} \quad$ mass of char fed into the fuel reactor $(\mathrm{kg})$

$m_{\text {elut }} \quad$ oxygen carrier elutriated from the batch fluidized bed reactor $(\mathrm{kg})$

$m_{F R} \quad$ mass of oxygen carrier in the fuel reactor $\left(\mathrm{kg} / \mathrm{MW}_{\mathrm{th}}\right)$

$m_{O x} \quad$ mass of fully oxidized oxygen carrier $(\mathrm{kg})$

$m_{O C} \quad$ mass of oxygen carrier in the air reactor $(\mathrm{kg})$

$m_{\text {red }} \quad$ mass of reduced oxygen carrier, as $\mathrm{Cu}_{2} \mathrm{O}(\mathrm{kg})$

$M_{\mathrm{O}_{2}} \quad$ molecular weight of oxygen $\left(=32 \cdot 10^{-3} \mathrm{~kg} / \mathrm{mol}\right)$

$N_{\mathrm{O}_{2}}$ amount of oxygen, expressed as $\mathrm{O}_{2}$, in the bed material (mol)

$r_{\mathrm{O}_{2}, \text { Red }}$ rate of oxygen generation in the reduction $\left(\mathrm{kg} \mathrm{O}_{2} / \mathrm{s}\right.$ per $\mathrm{kg}$ of oxygen carrier $)$

$r_{O_{2}, O x}$ rate of oxygen consumption in the oxidation $\left(\mathrm{kg} \mathrm{O}_{2} / \mathrm{s}\right.$ per $\mathrm{kg}$ of oxygen carrier)

$r_{O_{2}, \max }$ maximum rate of oxygen generation $\left(\mathrm{kg} \mathrm{O}_{2} / \mathrm{s}\right.$ per $\mathrm{kg}$ of oxygen carrier)

$R_{O C} \quad$ oxygen transport capacity (-)

$t \quad$ time (s)

$T \quad$ temperature $\left({ }^{\circ} \mathrm{C}\right)$

$T_{0} \quad$ initial temperature for the experiment $\left({ }^{\circ} \mathrm{C}\right)$

$T_{\max } \quad$ maximum temperature reached during the experiment $\left({ }^{\circ} \mathrm{C}\right)$

$X_{\mathrm{Ox}} \quad$ Oxygen carrier oxidation conversion (-)

$X_{\text {Red }} \quad$ Oxygen carrier reduction conversion (-) 
Submitted, accepted and published by

International Journal of Greenhouse Gas Control 65 (2017) 76-85

$X_{f} \quad$ oxygen carrier conversion at the end of the reducing period (-)

$y_{i} \quad$ molar fraction of gas $i(-)$

Greek symbols

$\Delta H_{r} \quad$ Enthalpy of reaction $(\mathrm{kJ} / \mathrm{mol})$

$v_{\text {attition }}$ Attrition rate $(\% / \mathrm{h})$

Acronyms

AJI Air Jet Index

BET Brunauer-Emmett-Teller

CLC Chemical Looping Combustion

CLOU Chemical Looping with Oxygen Uncoupling

OC Oxygen carrier

TGA Thermogravimetric analyser

XRD X-ray diffractometer 
Submitted, accepted and published by

International Journal of Greenhouse Gas Control 65 (2017) 76-85

Captions for Figures

Figure 1. $\mathrm{O}_{2}$ concentration at equilibrium as a function of the temperature for the $(-) \mathrm{CuO} / \mathrm{Cu}_{2} \mathrm{O},(\cdots$ ) $\mathrm{Mn}_{2} \mathrm{O}_{3} / \mathrm{Mn}_{3} \mathrm{O}_{4}$ and (---) $\mathrm{Co}_{3} \mathrm{O}_{4} / \mathrm{CoO}$ systems.

Figure 2. TGA Conversion vs time curves for: (a) reduction and (b) oxidation reactions at different temperatures; (c) effect of oxygen concentration on oxidation reaction at $800{ }^{\circ} \mathrm{C}$. Reduction: $\mathrm{N}_{2}$; Oxidation: air/ $\mathrm{N}_{2}$, in TGA.

Figure 3. $\mathrm{O}_{2}$ concentration as a function of time for 5 consecutive oxygen uncoupling-oxidation cycles in the batch fluidized bed reactor for gaseous fuels at $850^{\circ} \mathrm{C}$. Reduction: $\mathrm{N}_{2}$. Oxidation: $10 \mathrm{vol} \% \mathrm{O}_{2}$ in $\mathrm{N}_{2}$.

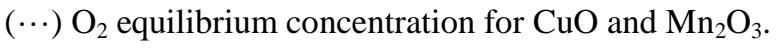

Figure 4. Oxygen concentration as a function of solids conversion during a reduction period using different bed temperatures in the batch fluidized bed reactor for gaseous fuels.

Figure 5. Solids conversion during one oxidation period in the batch fluidized bed reactor for gaseous fuels using different oxygen concentrations: 5,10 and $21 \mathrm{vol} \%$ at $\mathrm{T}=850^{\circ} \mathrm{C}$.

Figure 6. Attrition rate during multi-cycle operation in the batch fluidized bed for $\mathrm{N}_{2}$-air cycles of: Cu34Mn66-GR oxygen carrier (-•-) and hopcalite-derived oxygen carrier (-o-) (Adánez-Rubio et al., 2016).

Figure 7. Concentration of $\mathrm{O}_{2}, \mathrm{CO}_{2}, \mathrm{CO}, \mathrm{H}_{2}$ and $\mathrm{CH}_{4}$ during a typical reduction and oxidation cycle in the batch fluidized bed reactor for solid fuels. The variation in oxygen carrier conversion, $X_{O x}$, during the reduction and oxidation periods is also shown. $T_{0}=850^{\circ} \mathrm{C}$; reduction in $\mathrm{N}_{2}$ and oxidation with $10 \mathrm{vol} \%$ $\mathrm{O}_{2}$ in $\mathrm{N}_{2}$; mass fraction of oxygen carrier: $100 \mathrm{wt} \%$; Char batch: $2 \mathrm{~g}$. OC/char ratio $=143$. 
Submitted, accepted and published by

International Journal of Greenhouse Gas Control 65 (2017) 76-85

Figure 8. Instantaneous oxygen generation rate, $r_{\mathrm{O}_{2}}$,red , as a function of the oxygen carrier to char mass ratio. $T_{0}=850^{\circ} \mathrm{C}$. Mass fraction oxygen carrier in the reactor: $(\bullet) 100 \mathrm{wt} \% ;(\boldsymbol{\Delta}) 2.5 \mathrm{wt} \%$.

Figure 9. Instantaneous oxygen transfer rate, $r_{\mathrm{O}_{2}}$,red , for Cu34Mn66-GR as a function of the oxygen carrier to fuel mass ratio. Fuel: $(\Delta)$ coal; $(\boldsymbol{\Delta})$ char. $(\circ)$ hopcalite-derived oxygen carrier using coal as fuel (Adánez-Rubio et al., 2016). $T_{0}=850^{\circ} \mathrm{C}$. Mass fraction of oxygen carrier in the reactor: $2.5 \mathrm{wt} \%$.

Figure 10. TGA Conversion vs time curves for reduction reaction for fresh and used particles after $35 \mathrm{~h}$ in the batch fluidized bed reactor for $\mathrm{N}_{2}$-Air cycles $(\cdots)$ and $45 \mathrm{~h}$ in the batch fluidized bed reactor for gaseous fuels (--). Reduction: $\mathrm{N}_{2}$; Oxidation: air, at $950^{\circ} \mathrm{C}$ in TGA.

Figure 11. SEM images of fresh (left) and used particles after $35 \mathrm{~h}$ in the batch fluidized bed reactor for $\mathrm{N}_{2}$-air (middle) and used particles after $45 \mathrm{~h}$ in the batch fluidized bed reactor for solid fuels (right): (a, d, g) image of the particles; (b, d, f) cross section of a particle; (c, f, i) surface image of the oxygen carrier particle. 
Submitted, accepted and published by

International Journal of Greenhouse Gas Control 65 (2017) 76-85

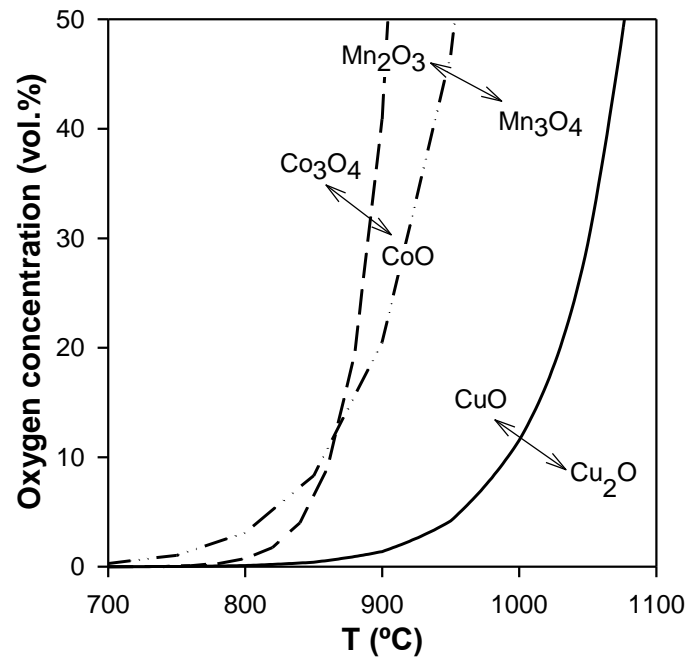

Figure 1. $\mathrm{O}_{2}$ concentration at equilibrium as a function of the temperature for the $(-) \mathrm{CuO} / \mathrm{Cu}_{2} \mathrm{O},(-\cdots-$ ) $\mathrm{Mn}_{2} \mathrm{O}_{3} / \mathrm{Mn}_{3} \mathrm{O}_{4}$ and (---) $\mathrm{Co}_{3} \mathrm{O}_{4} / \mathrm{CoO}$ systems. 
Submitted, accepted and published by

International Journal of Greenhouse Gas Control 65 (2017) 76-85

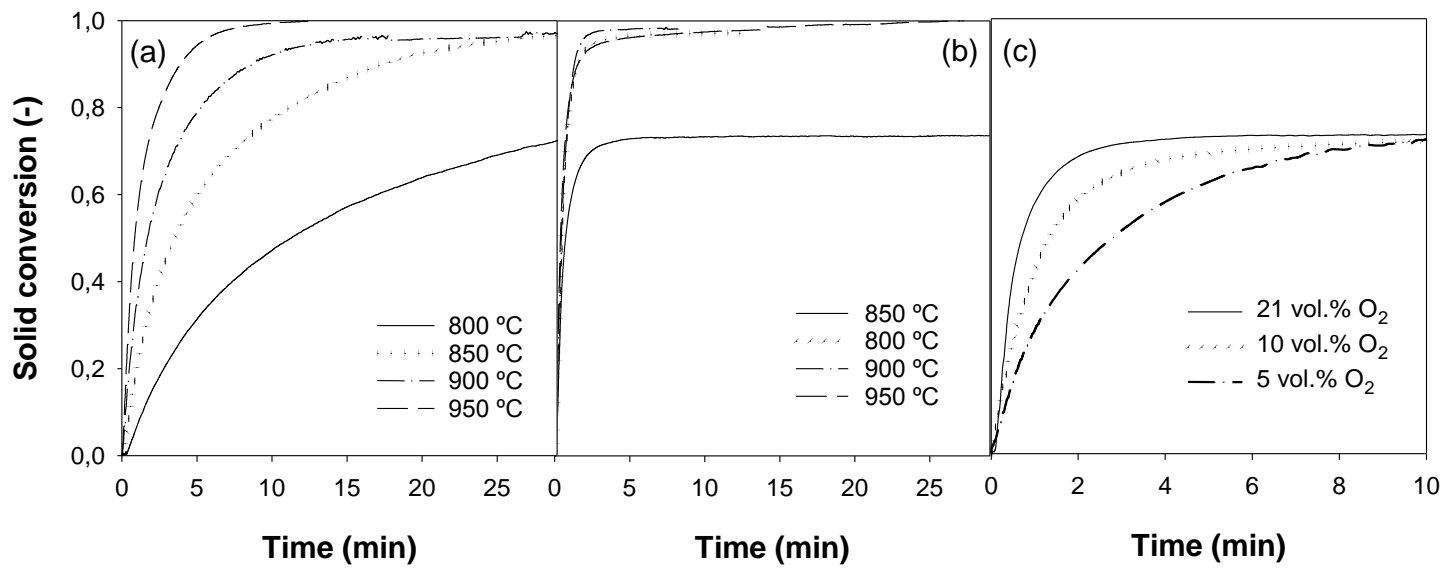

Figure 2. TGA Conversion vs. time curves for: (a) reduction and (b) oxidation reactions at different temperatures; (c) effect of oxygen concentration on oxidation reaction at $800{ }^{\circ} \mathrm{C}$. Reduction: $\mathrm{N}_{2}$;

Oxidation: air/ $\mathrm{N}_{2}$, in TGA. 
Submitted, accepted and published by

International Journal of Greenhouse Gas Control 65 (2017) 76-85

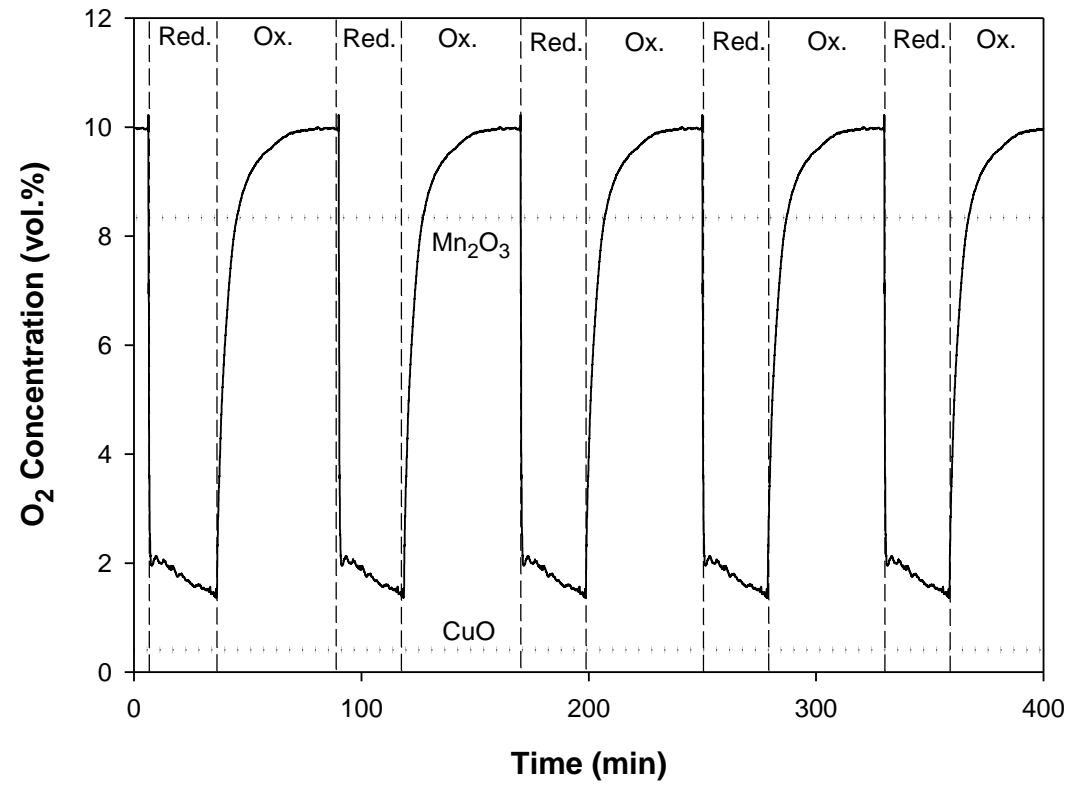

Figure 3. $\mathrm{O}_{2}$ concentration as a function of time for 5 consecutive oxygen uncoupling-oxidation cycles in the batch fluidized bed reactor for gaseous fuels at $850^{\circ} \mathrm{C}$. Reduction: $\mathrm{N}_{2}$. Oxidation: 10 vol\% $\mathrm{O}_{2}$ in $\mathrm{N}_{2}$. (...) $\mathrm{O}_{2}$ equilibrium concentration for $\mathrm{CuO}$ and $\mathrm{Mn}_{2} \mathrm{O}_{3}$. 
Submitted, accepted and published by

International Journal of Greenhouse Gas Control 65 (2017) 76-85

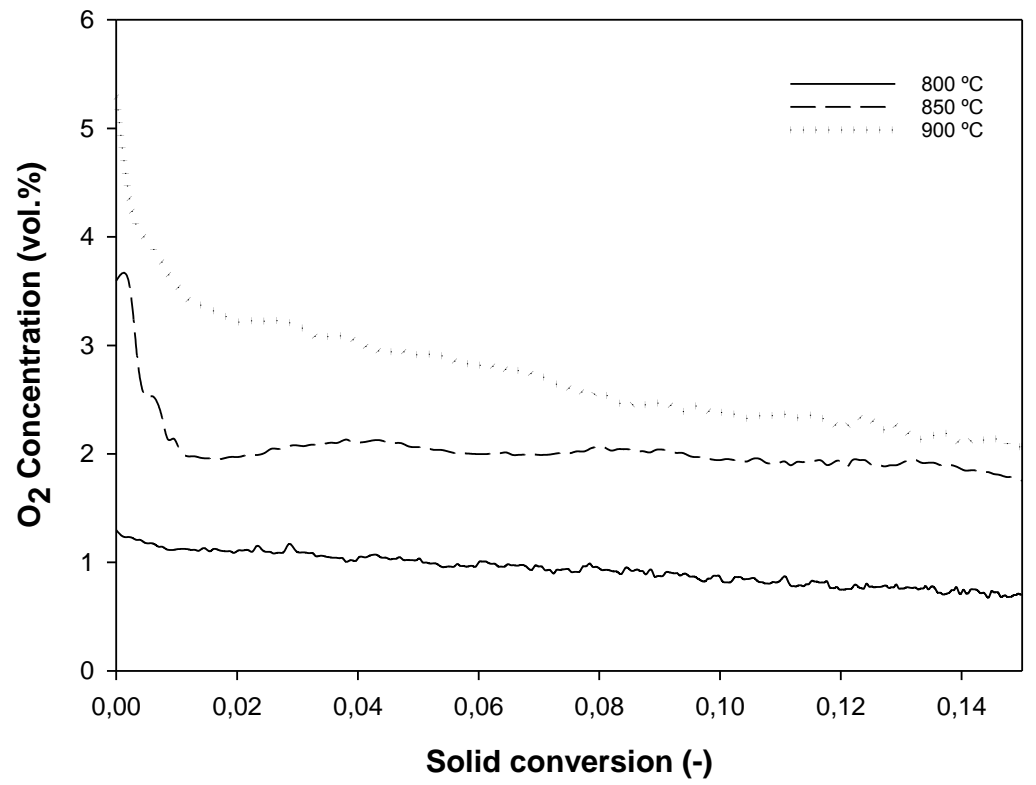

Figure 4. Oxygen concentration as a function of solids conversion during a reduction period using different bed temperatures in the batch fluidized bed reactor for gaseous fuels. 
Submitted, accepted and published by International Journal of Greenhouse Gas Control 65 (2017) 76-85

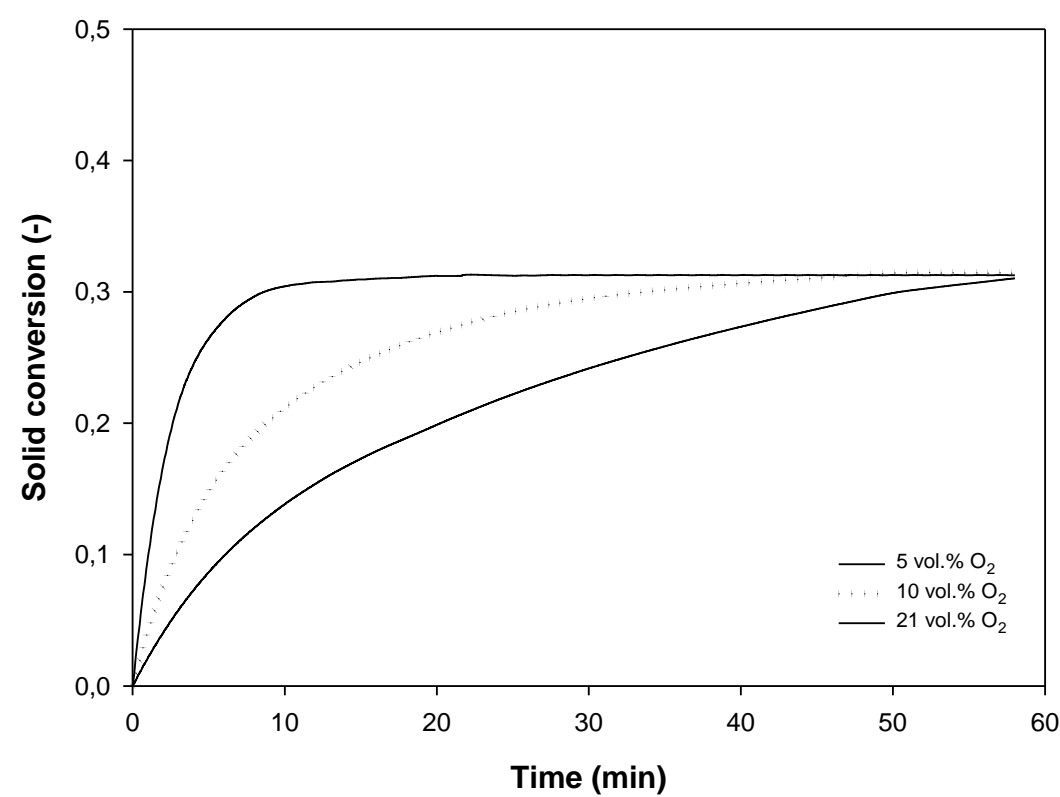

Figure 5. Solids conversion during one oxidation period in the batch fluidized bed reactor for gaseous fuels using different oxygen concentrations: 5,10 and $21 \mathrm{vol} \%$ at $\mathrm{T}=850^{\circ} \mathrm{C}$. 
Submitted, accepted and published by

International Journal of Greenhouse Gas Control 65 (2017) 76-85

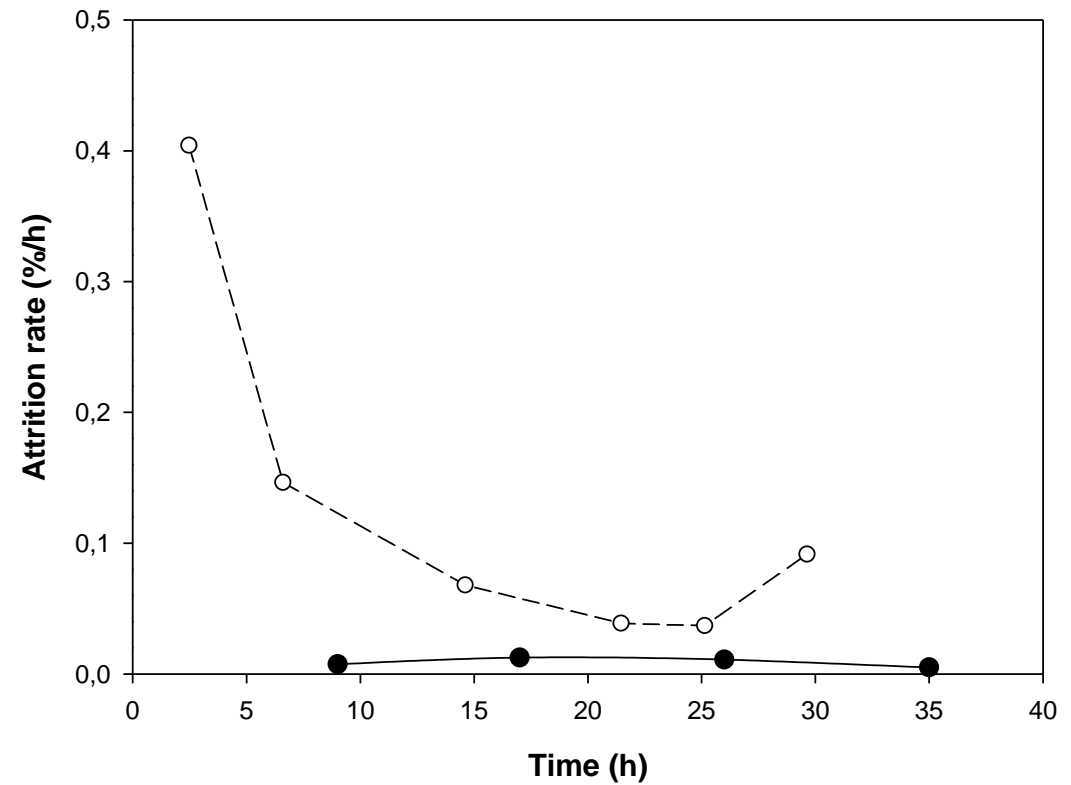

Figure 6. Attrition rate during multi-cycle operation in the batch fluidized bed for $\mathrm{N}_{2}$-air cycles of:

Cu34Mn66-GR oxygen carrier (-•-); and hopcalite-derived oxygen carrier (-০-) (Adánez-Rubio et al., 2016). 
Submitted, accepted and published by International Journal of Greenhouse Gas Control 65 (2017) 76-85

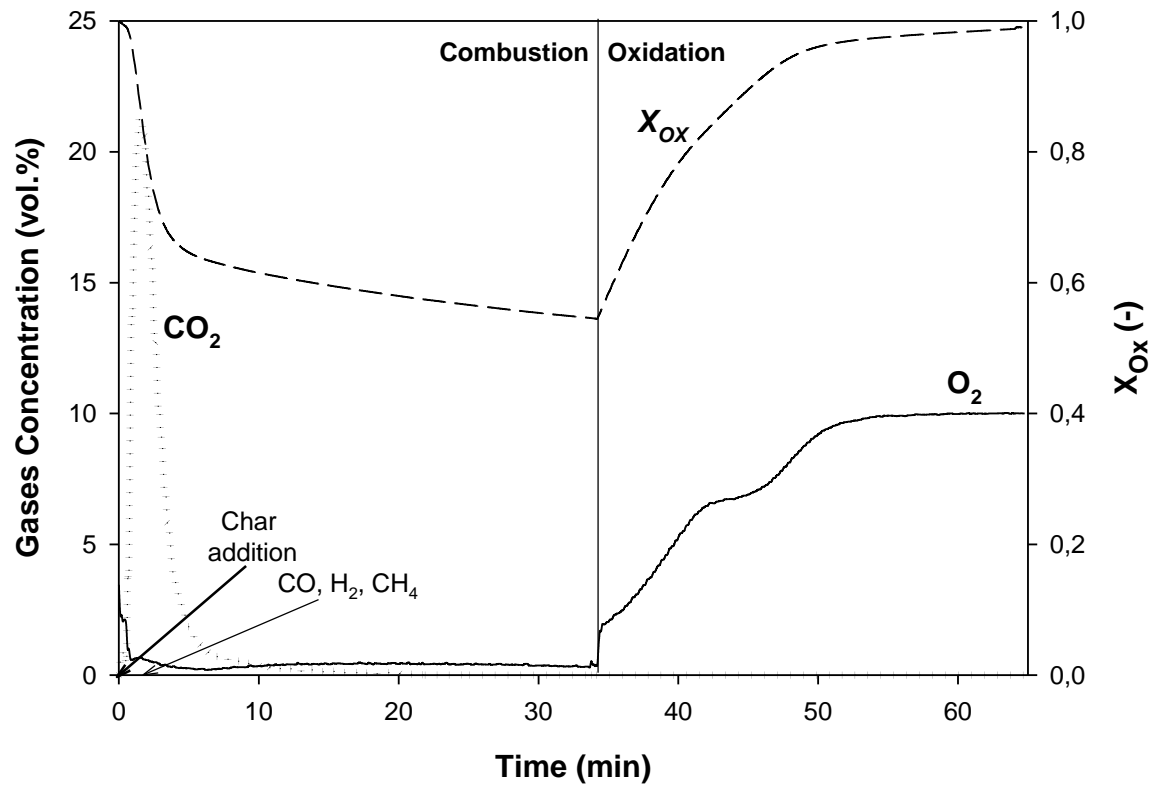

Figure 7. Concentration of $\mathrm{O}_{2}, \mathrm{CO}_{2}, \mathrm{CO}, \mathrm{H}_{2}$ and $\mathrm{CH}_{4}$ during a typical reduction and oxidation cycle in the batch fluidized bed reactor for solid fuels. The variation in oxygen carrier conversion, $X_{O x}$, during the reduction and oxidation periods is also shown. $T_{0}=850^{\circ} \mathrm{C}$; reduction in $\mathrm{N}_{2}$ and oxidation with 10 vol $\%$ $\mathrm{O}_{2}$ in $\mathrm{N}_{2}$; mass fraction of oxygen carrier: $100 \mathrm{wt} \%$; Char batch: $2 \mathrm{~g}$. OC/char ratio $=143$. 
Submitted, accepted and published by

International Journal of Greenhouse Gas Control 65 (2017) 76-85

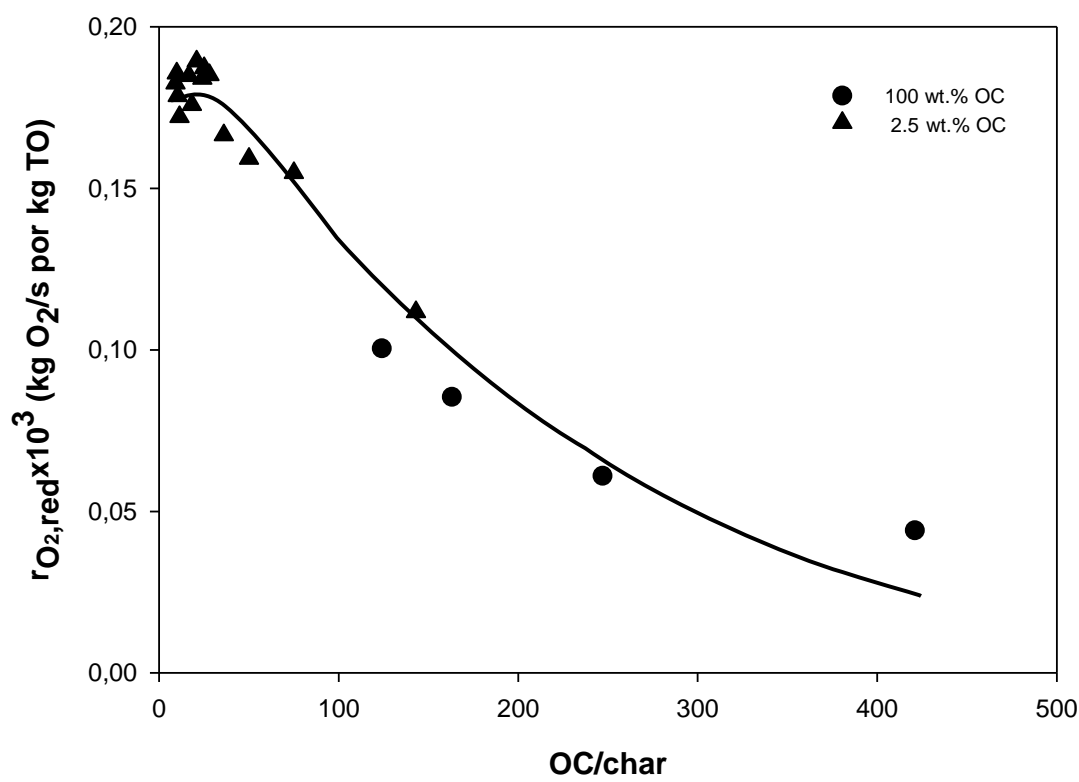

Figure 8. Instantaneous oxygen generation rate, $r_{O_{2}, \text { red }}$, as a function of the oxygen carrier to char mass ratio. $T_{0}=850^{\circ} \mathrm{C}$. Mass fraction oxygen carrier in the reactor: $(\bullet) 100 \mathrm{wt} \% ;(\boldsymbol{\Delta}) 2.5 \mathrm{wt} \%$. 
Submitted, accepted and published by

International Journal of Greenhouse Gas Control 65 (2017) 76-85

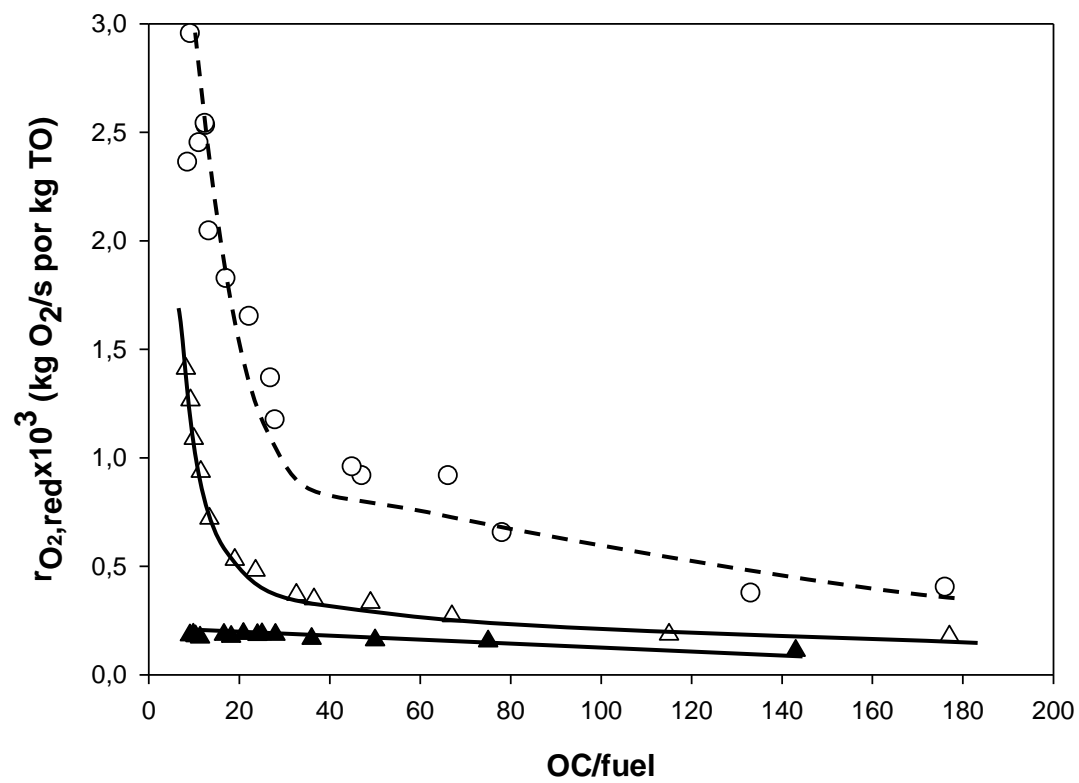

Figure 9. Instantaneous oxygen transference rate, $r_{O_{2}, \text { red }}$, for Cu34Mn66-GR as a function of the oxygen carrier to fuel mass ratio. Fuel: $(\Delta)$ coal; $(\boldsymbol{\Delta})$ char. $(\circ)$ hopcalite-derived oxygen carrier using coal as fuel (Adánez-Rubio et al., 2016). $T_{0}=850^{\circ} \mathrm{C}$. Mass fraction of oxygen carrier in the reactor: $2.5 \mathrm{wt} \%$. 
Submitted, accepted and published by

International Journal of Greenhouse Gas Control 65 (2017) 76-85

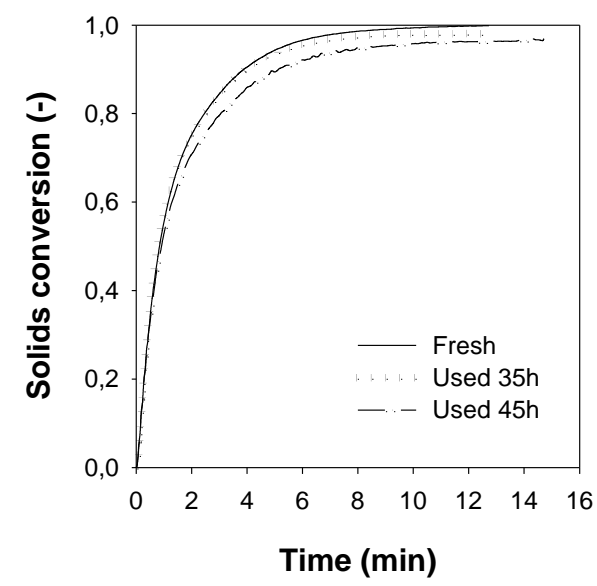

Figure 10. TGA Conversion vs time curves for reduction reaction for fresh and used particles after $35 \mathrm{~h}$ in the batch fluidized bed reactor for $\mathrm{N}_{2}$-Air cycles $(\cdots)$ and $45 \mathrm{~h}$ in the batch fluidized bed reactor for gaseous fuels (-·). Reduction: $\mathrm{N}_{2}$; Oxidation: air, at $950{ }^{\circ} \mathrm{C}$ in TGA. 
Submitted, accepted and published by

International Journal of Greenhouse Gas Control 65 (2017) 76-85

$\begin{array}{lll}\text { Fresh } & \text { Used } 35 \mathrm{~h} & \text { Used } 45 \mathrm{~h}\end{array}$

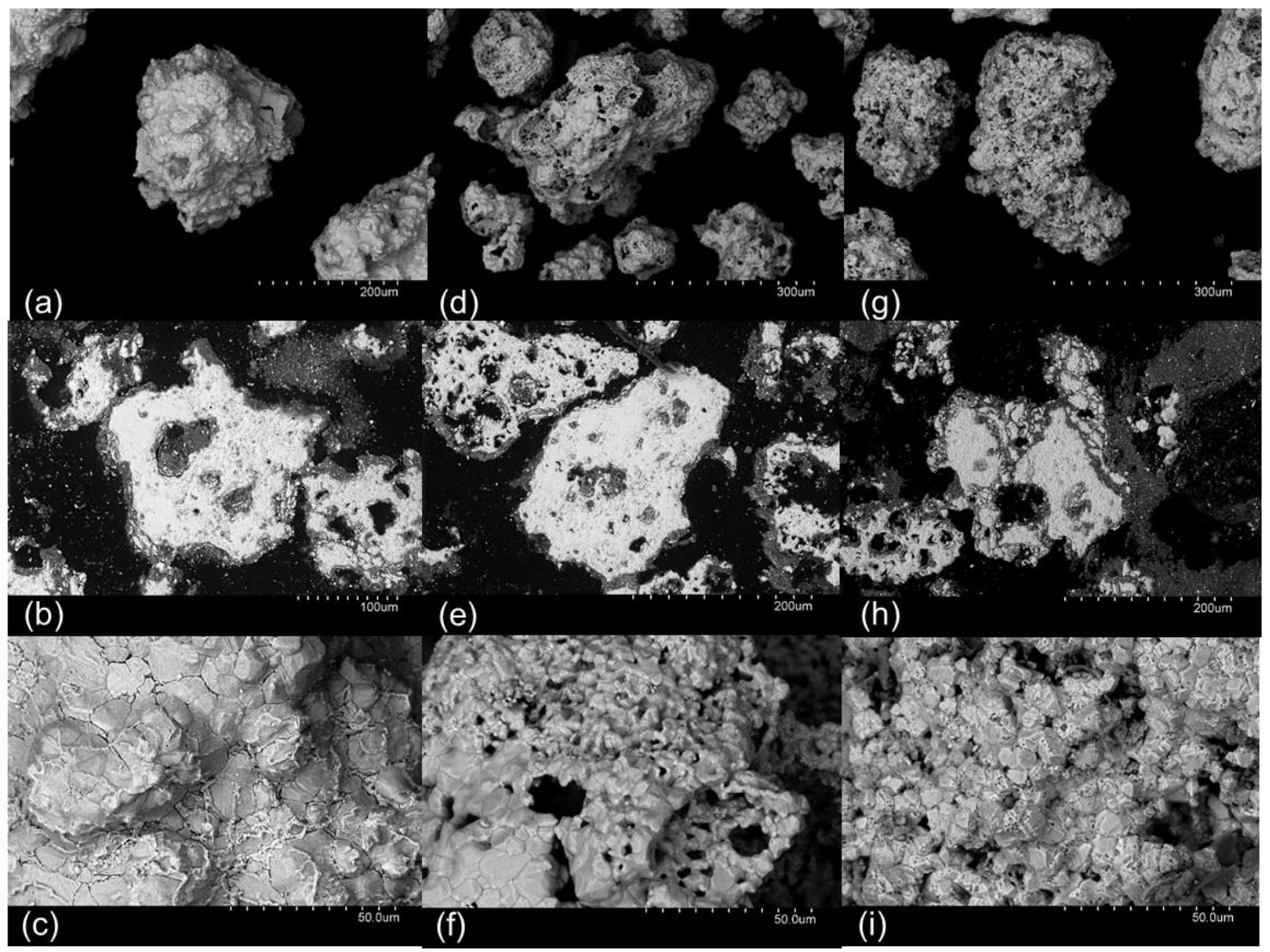

Figure 11. SEM images of fresh (left) and used particles after $35 \mathrm{~h}$ in the batch fluidized bed reactor for $\mathrm{N}_{2}$-air (middle) and used particles after $45 \mathrm{~h}$ in the batch fluidized bed reactor for solid fuels (right): (a, d, g) image of the particles; (b, d, f) cross section of a particle; (c, f, i) surface image of the oxygen carrier particle. 
Submitted, accepted and published by

International Journal of Greenhouse Gas Control 65 (2017) 76-85

\section{Captions for tables}

Table 1. Properties of the oxygen carrier particles, fresh, used after $35 \mathrm{~h}$ in the batch fluidized bed reactor for gases, and after $45 \mathrm{~h}$ in the batch fluidized bed reactor for solid fuels.

Table 2. Properties of South African coal and the char prepared.

Table 3. Maximum oxygen generation rate value, $\mathrm{r}_{\mathrm{O}_{2}, \max }$, for the Cu34Mn66-GR and hopcalite-derived oxygen carrier (Adánez-Rubio et al., 2016) as a function of the temperature. 
Submitted, accepted and published by

International Journal of Greenhouse Gas Control 65 (2017) 76-85

Table 1. Properties of the oxygen carrier particles, fresh, used after $35 \mathrm{~h}$ in the batch fluidized bed reactor for gases, and after $45 \mathrm{~h}$ in the batch fluidized bed reactor for solid fuels.

\begin{tabular}{llll}
\hline & Fresh & Used 35h & Used 45h \\
\hline XRD main phases & $\mathrm{Cu}_{1.5} \mathrm{Mn}_{1.5} \mathrm{O}_{4}$, & $\mathrm{Cu}_{1.5} \mathrm{Mn}_{1.5} \mathrm{O}_{4}$, & $\mathrm{Cu}_{1.5} \mathrm{Mn}_{1.5} \mathrm{O}_{4}$, \\
& $\mathrm{Mn}_{3} \mathrm{O}_{4}$ & $\mathrm{Mn}_{3} \mathrm{O}_{4}$ & $\mathrm{Mn}_{2} \mathrm{O}_{3}, \mathrm{Mn}_{3} \mathrm{O}_{4}$ \\
Composition (wt\%) & $72 \% \mathrm{Cu}_{1.5} \mathrm{Mn}_{1.5} \mathrm{O}_{4}$ & $72 \% \mathrm{Cu}_{1.5} \mathrm{Mn}_{1.5} \mathrm{O}_{4}$ & $72 \% \mathrm{Cu}_{1.5} \mathrm{Mn}_{1.5} \mathrm{O}_{4}$ \\
& $28 \% \mathrm{Mn}_{3} \mathrm{O}_{4}$ & $28 \% \mathrm{Mn}_{3} \mathrm{O}_{4}$ & $23 \% \mathrm{Mn}_{3} \mathrm{O}_{4}$ \\
& & & $5 \% \mathrm{Mn}_{2} \mathrm{O}_{3}$ \\
CLOU Oxygen transport capacity, & 4.0 & 4.0 & 4.0 \\
$R_{O C}(\mathrm{wt} \%)$ & 1.9 & 1.3 & 1.3 \\
Crushing strength (N) & 4100 & 4100 & 4100 \\
Skeletal density of particles $\left(\mathrm{kg} / \mathrm{m}^{3}\right)$ & 3.0 & 3.2 & 4.1 \\
AJI $(\%)$ & 12.1 & 11.5 & 10.8 \\
Porosity (\%) & $<0.5$ & $<0.5$ & $<0.5$ \\
Specific surface area, BET $\left(\mathrm{m}^{2} / \mathrm{g}\right)$ & & & \\
\hline
\end{tabular}


Submitted, accepted and published by

International Journal of Greenhouse Gas Control 65 (2017) 76-85

Table 2. Properties of South African coal and the char prepared.

\begin{tabular}{lll} 
& $\begin{array}{l}\text { Medium Volatile } \\
\text { Bituminous }\end{array}$ & Char coal \\
\hline Proximate Analysis (wt\%) & \\
\hline $\mathrm{C}$ & 69.3 & 76.5 \\
$\mathrm{H}$ & 4.0 & 0.2 \\
$\mathrm{~N}$ & 2.0 & 1.6 \\
$\mathrm{~S}$ & 1.0 & 0.8 \\
$\mathrm{O}^{(1)}$ & 5.2 & 0.0 \\
\hline Ultimate Analysis (wt\%) & \\
\hline Moisture & 4.2 & 0.9 \\
Volatile matter & 25.5 & 1.1 \\
Fixed carbon & 56.0 & 78.0 \\
Ash & 14.3 & 20.0 \\
\hline (1) to balance & &
\end{tabular}


Submitted, accepted and published by

International Journal of Greenhouse Gas Control 65 (2017) 76-85

Table 3. Maximum oxygen generation rate value, $\mathrm{r}_{\mathrm{O}_{2} \text {, max }}$, for the Cu34Mn66-GR and hopcalite-derived oxygen carrier (Adánez-Rubio et al., 2016) as a function of the temperature.

\begin{tabular}{|c|c|c|c|}
\hline$T_{0}\left({ }^{\circ} \mathrm{C}\right)$ & $T_{\max }\left({ }^{\circ} \mathrm{C}\right)$ & $\begin{array}{c}\mathrm{Cu} 34 \mathrm{Mn} 66-\mathrm{GR} \\
\mathrm{r}_{\mathrm{O}_{2}, \max } \cdot \mathbf{1 0}^{\mathbf{3}} \\
\text { (kg O } \mathbf{O}_{2} / \mathbf{s ~ p e r ~ k g ~ O C )} \\
\end{array}$ & 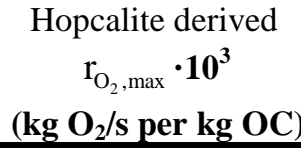 \\
\hline 800 & 830 & 0.08 & --- \\
\hline 825 & 855 & 0.15 & --- \\
\hline 850 & 980 & 0.19 & 0.30 \\
\hline 900 & 930 & 0.25 & 0.61 \\
\hline
\end{tabular}

